
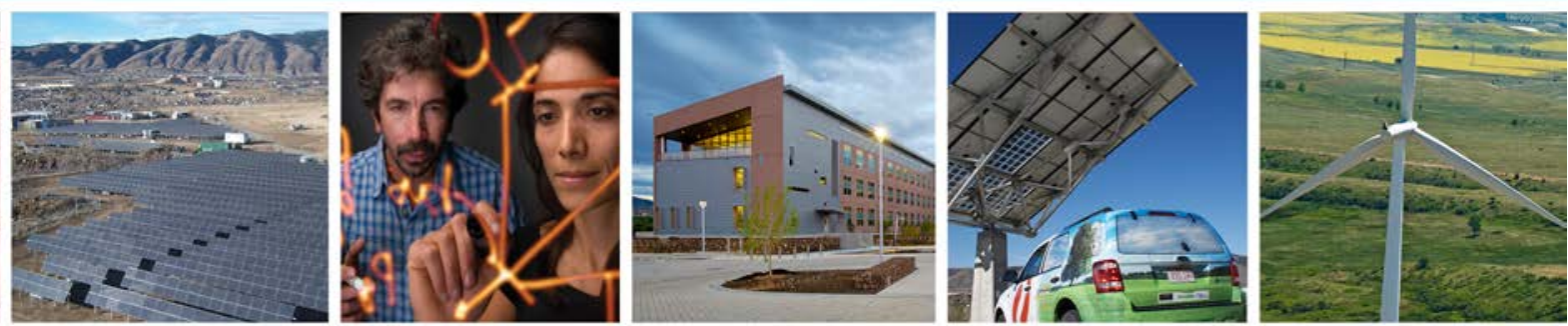

\title{
Clean Cities 2012 Annual Metrics Report
}

Caley Johnson National Renewable Energy Laboratory

NREL is a national laboratory of the U.S. Department of Energy Office of Energy Efficiency \& Renewable Energy Operated by the Alliance for Sustainable Energy, LLC.

This report is available at no cost from the National Renewable Energy Laboratory (NREL) at www.nrel.gov/publications.

Technical Report

NREL/TP-5400-60274

December 2013

Contract No. DE-AC36-08G028308 


\section{Clean Cities 2012 Annual Metrics Report}

\section{Caley Johnson}

National Renewable Energy Laboratory

Prepared under Task No. VTP2.0020

NREL is a national laboratory of the U.S. Department of Energy Office of Energy Efficiency \& Renewable Energy Operated by the Alliance for Sustainable Energy, LLC.

This report is available at no cost from the National Renewable Energy Laboratory (NREL) at www.nrel.gov/publications.

\section{Technical Report}

NREL/TP-5400-60274

December 2013 


\section{NOTICE}

This report was prepared as an account of work sponsored by an agency of the United States government. Neither the United States government nor any agency thereof, nor any of their employees, makes any warranty, express or implied, or assumes any legal liability or responsibility for the accuracy, completeness, or usefulness of any information, apparatus, product, or process disclosed, or represents that its use would not infringe privately owned rights. Reference herein to any specific commercial product, process, or service by trade name, trademark, manufacturer, or otherwise does not necessarily constitute or imply its endorsement, recommendation, or favoring by the United States government or any agency thereof. The views and opinions of authors expressed herein do not necessarily state or reflect those of the United States government or any agency thereof.

This report is available at no cost from the National Renewable Energy Laboratory (NREL) at www.nrel.gov/publications.

Available electronically at http://www.osti.gov/bridge

Available for a processing fee to U.S. Department of Energy and its contractors, in paper, from:

U.S. Department of Energy

Office of Scientific and Technical Information

P.O. Box 62

Oak Ridge, TN 37831-0062

phone: 865.576 .8401

fax: 865.576 .5728

email: mailto:reports@adonis.osti.gov

Available for sale to the public, in paper, from:

U.S. Department of Commerce

National Technical Information Service

5285 Port Royal Road

Springfield, VA 22161

phone: 800.553 .6847

fax: 703.605.6900

email: orders@ntis.fedworld.gov

online ordering: http://www.ntis.gov/help/ordermethods.aspx

Cover Photos: (left to right) photo by Pat Corkery, NREL 16416, photo from SunEdison, NREL 17423, photo by Pat Corkery, NREL 16560, photo by Dennis Schroeder, NREL 17613, photo by Dean Armstrong, NREL 17436, photo by Pat Corkery, NREL 17721. 


\section{Table of Contents}

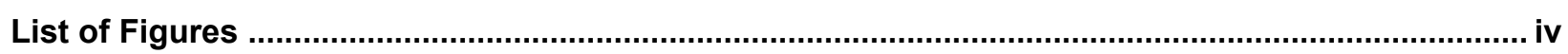

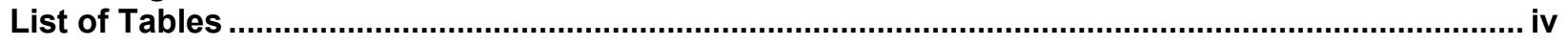

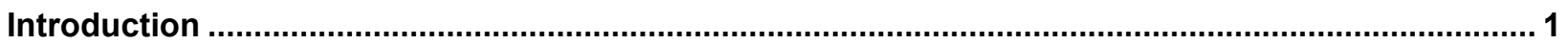

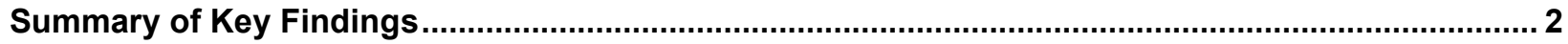

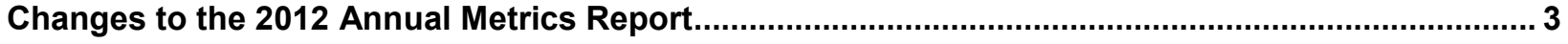

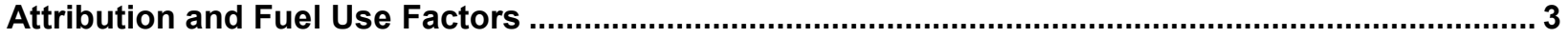

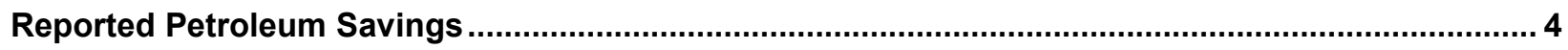

Alternative Fuels and Vehicles................................................................................ 4

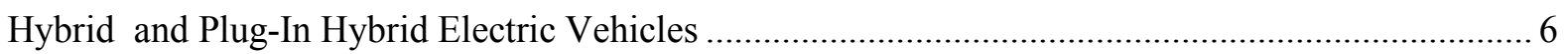

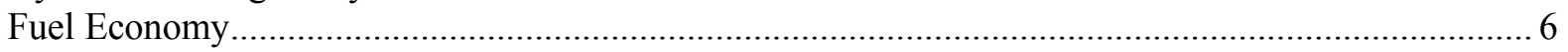

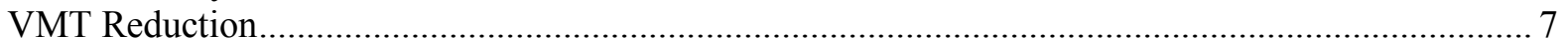

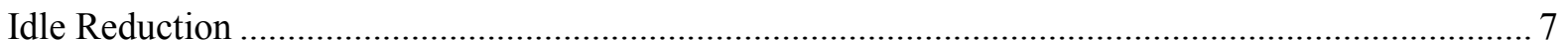

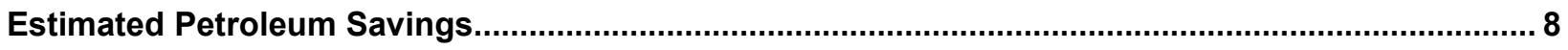

Methods Used to Estimate Petroleum Use Reduction by Websites and Outreach Activities ............... 8

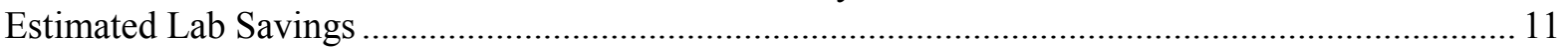

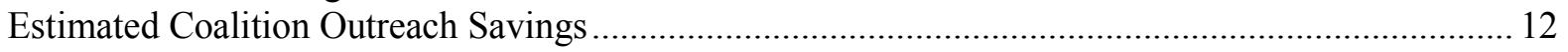

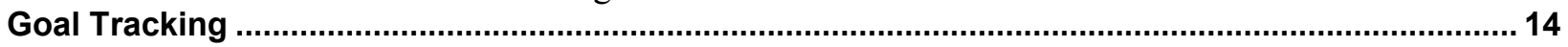

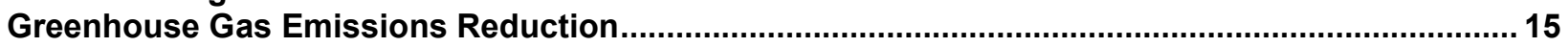

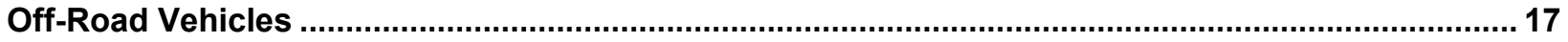



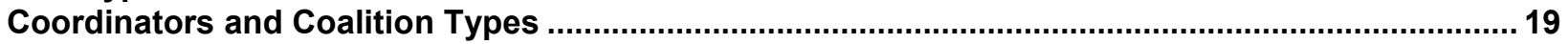

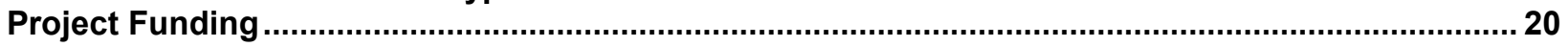

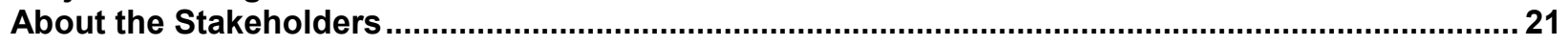

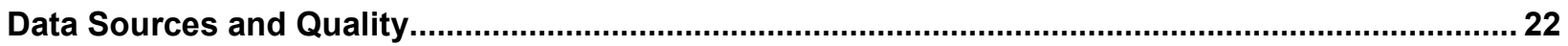

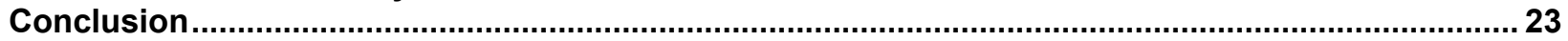

Appendix A: Clean Cities Coalitions that Completed 2012 Annual Reports .................................... 24 


\section{List of Figures}

Figure 1. Number of AFVs and petroleum savings from fuel type.................................................. 4

Figure 2. Average fuel-use reduction per vehicle for 2012 fuel economy projects .......................... 6

Figure 3. Fuel savings from idle-reduction projects ................................................................ 8

Figure 4. Percent of outreach activities split among audience types ........................................13

Figure 5. Percent of outreach activities by technology type ...........................................................14

Figure 6. Annual petroleum savings trajectory to meet 2020 goal and actual progress..................15

Figure 7. Number of AFVs and amount of GHG reduction by fuel type ............................................17

Figure 8. Percentage of total AFVs by market/owner............................................................19

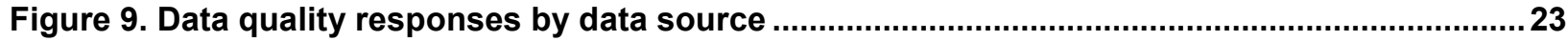

\section{List of Tables}

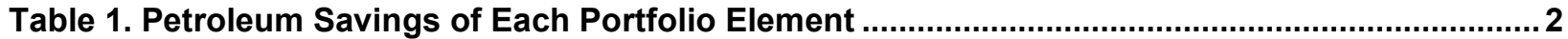

Table 2. Average Annual Petroleum Displacement per Vehicle...................................................... 5

Table 3. VMT Reduction Project Types, Number, and Displacement ................................................. 7

Table 4. Benchmark Customer Conversion Rates and Their Sources............................................. 9

Table 5. Relationships for Media Effectiveness and Their Sources. ..............................................10

Table 6. Combination of Benchmarks and Relationships. .............................................................. 10

Table 7. Customer Conversion Ratios Used in the PIM .................................................................11

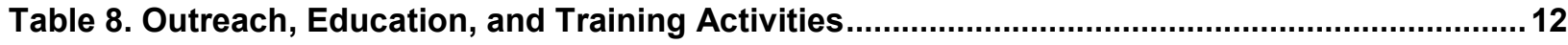

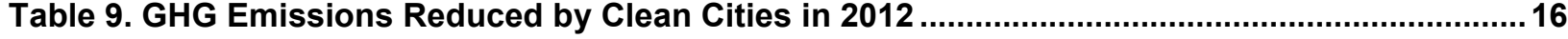

Table 10. Number of Non-Road Vehicles or Equipment and Petroleum Saved................................18

Table 11. Number and Type of AFVs by Fuel Type .....................................................................

Table 12. Indicators of Coalition Success by Coalition Type ..........................................................20

Table 13. Breakdown of 2012 Project Awards by Number and Value ..........................................21 


\section{Introduction}

The U.S. Department of Energy's (DOE) Clean Cities program advances the nation's economic, environmental, and energy security by supporting local actions to cut petroleum use in transportation. A national network of nearly 100 Clean Cities coalitions brings together stakeholders in the public and private sectors to deploy alternative and renewable fuels, idlereduction measures, fuel economy improvements, and new transportation technologies, as they emerge.

Each year DOE asks Clean Cities coordinators to submit annual reports of their activities and accomplishments for the previous calendar year. Data and information are submitted via an online database that is maintained as part of the Alternative Fuels Data Center (AFDC) at the National Renewable Energy Laboratory (NREL). Coordinators submit a range of data that characterizes the membership, funding, projects, and activities of their coalitions. They also submit data about sales of alternative fuels, deployment of alternative fuel vehicles (AFVs) and hybrid electric vehicles (HEVs), idle-reduction initiatives, fuel economy activities, and programs to reduce vehicle miles traveled (VMT). NREL analyzes the data and translates them into petroleum-use reduction impacts, which are summarized in this report.

Eighty-three of the 85 coalitions that were active throughout 2012 completed reports, representing a response rate of $97 \%$. The coalitions that submitted 2012 annual reports are listed in the appendix to this report. Coalition coordinators assembled the data based on voluntary reports from their stakeholders - the private and public entities that are members of the coalitions. As such, each of these reports represent a subset of the Clean Cities activities throughout the nation, and taken together, they are an important indicator of the impact of the coalitions.

In addition to collecting data through the coordinator reports, NREL compiles metrics about activities funded by the Clean Cities program at NREL and Oak Ridge National Laboratory (ORNL). NREL provides a range of technical data, tools, and resources to support coalitions in their efforts to accelerate the use of alternative fuels, advanced vehicles, and other technologies. ORNL produces the Fuel Economy Guide, the FuelEconomy.gov website, and other public information related to fuel economy. Metrics pertaining to the use and impact of these resources are presented in this report.

A compilation of data from this report, along with reports from previous years, can be accessed at www.eere.energy.gov/afdc/data/cleancities.html. Previous years reports can be downloaded in their entirety at http://www.afdc.energy.gov/. 


\section{Summary of Key Findings}

Clean Cities activities saved ${ }^{1}$ approximately 907 million gallons of gasoline in 2012 . Table 1 shows the combined results of two categories of petroleum savings:

"Core Activities" include activities reported by coalitions and national laboratory websites, as analyzed by NREL and ORNL. "Estimated Coalition Outreach Savings" result from coalition outreach, education, and training events, as estimated by NREL and ORNL.

As shown below in Table 1, savings from core activities increased 15\% in 2012, while estimated outreach savings increased 3\%. The large increase in savings from ORNL fuel economy work is likely due to the increase in vehicle research caused by the rebounding of the vehicle market in 2012. Total 2012 petroleum savings increased 13\% relative to 2011, keeping the Clean Cities program ahead of schedule to meet its goal of 2.5 billion gallons per year by 2020 .

Table 1. Petroleum Savings of Each Portfolio Element

\begin{tabular}{|c|c|c|c|c|}
\hline Technology & $\begin{array}{c}\text { Million GGEs } \\
\text { Saved }\end{array}$ & $\begin{array}{l}\text { Percent of Total } \\
\text { Core Savings }\end{array}$ & $\begin{array}{c}\text { Percent of Grand } \\
\text { Total Savings }\end{array}$ & $\begin{array}{c}\text { Increase from } \\
\text { Last Year }\end{array}$ \\
\hline Alt. Fuels and Vehicles & 347.7 & $48 \%$ & $38 \%$ & $0 \%$ \\
\hline VMT Reduction & 40.5 & $6 \%$ & $4 \%$ & $22 \%$ \\
\hline œ HEVs \& PHEVs & 40.3 & $6 \%$ & $4 \%$ & $17 \%$ \\
\hline$\stackrel{\infty}{\stackrel{D}{*}}$ Idle Reduction & 31.1 & $4 \%$ & $3 \%$ & $-4 \%$ \\
\hline Fuel Economy & 13.6 & $2 \%$ & $1 \%$ & $30 \%$ \\
\hline$\stackrel{\ll}{\circlearrowright}$ Off-Road & 6.6 & $1 \%$ & $1 \%$ & $14 \%$ \\
\hline ১̀ ORNL Fuel Economy & 176.6 & $24 \%$ & $19 \%$ & $72 \%$ \\
\hline AFDC & 69.3 & $10 \%$ & $8 \%$ & $13 \%$ \\
\hline $\begin{array}{l}\text { Total Savings from } \\
\text { Core Activities }\end{array}$ & 725.7 & $100 \%$ & $27 \%$ & $15 \%$ \\
\hline $\begin{array}{l}\text { Estimated Coalition Outreach } \\
\text { Savings }\end{array}$ & 181.6 & - & $20 \%$ & $3 \%$ \\
\hline Grand Total & 907.3 & - & $100 \%$ & $13 \%$ \\
\hline
\end{tabular}

* Totals may differ from the sums of subcategories due to rounding.

Clean Cities' core activities prevented over 5 million tons of carbon dioxide equivalent $\left(\mathrm{CO}_{2} \mathrm{e}\right)$ from being emitted to the atmosphere. Outreach events kept another 1.6 million tons of $\mathrm{CO}_{2} \mathrm{e}$ out of the atmosphere, for a total of 6.6 million tons $\mathrm{CO}_{2} \mathrm{e}$. This greenhouse gas (GHG) emissions reduction is equivalent to removing 1.5 million cars from U.S. roads.

1. The petroleum saved includes both gasoline and diesel. Petroleum savings in this report are expressed in gasoline-gallon equivalents (GGE), using the lower heating value ratio of the fuels. 
Coalitions were also remarkably successful in leveraging DOE's investment in the program. In 2012, the coalitions won 187 new project awards (project-specific grants) worth a total of $\$ 122$ million and another $\$ 89$ million in leveraged funds from coalition members. This funding represents an 8:1 leveraging of the $\$ 28$ million Clean Cities program budget in Fiscal Year (FY) 2012.

Clean Cities coordinators spent more than 130,000 hours pursuing Clean Cities' goals in 2012, which is equivalent to having a national network of 67 full-time technical and sales professionals working in the field to reduce U.S. dependence on petroleum. Coordinators logged 2,338 outreach, education, and training activities in 2012, which reached an estimated 109 million people and saved an estimated 182 million GGEs of petroleum. The general public was the most common audience at these events, followed by government fleets.

\section{Changes to the 2012 Annual Metrics Report}

To assure continuity of data from one year to the next, we made very few changes to the Clean Cities Annual Metrics Report and reporting process in 2012. Most changes were small and were implemented to increase the accuracy and thoroughness of the reporting process. These changes include the following:

We started tracking vehicle type and market for HEVs and plug-in hybrid electric vehicles (PHEVs).

We added a new section for electric vehicles (EVs), PHEVs, and HEVs that enabled coordinators to input the amount of electricity used (in kWh) or the efficiency of their EVs (in the industrystandard $\mathrm{kWh} / 100$ miles). This new format allows more flexibility for data input and more data refinement for analysis of vehicle performance.

We started tracking coalition types and analyzing the relationship between coalition types and indicators of success.

Coordinators reported whether their projects included a National Partner.

We limited, more stringently than in previous years, the portion of a project that coordinators could claim for their coalitions. This led to Clean Cities claiming smaller portions of the petroleum and GHG reductions for numerous projects.

\section{Attribution and Fuel Use Factors}

To clarify the link between coalition activities and end results, the coalition annual report includes an attribution factor that accounts for the percentage of a project's outcome that may be due to coalition activities rather than to the activities of other project participants. This attribution factor was used in the estimates of impacts for fuel economy, VMT reduction, idle reduction, alternative fuel use, and outreach projects. Coordinators estimated the percentage of the project's outcome their coalition was responsible for, and the project's overall outcome was multiplied by that percentage to determine the coalition's impact. Although subjective, this method attempts to address the issue of attribution where a coalition is one of several partners involved in a project. To reduce the subjectivity of this factor, NREL added a tool to help a coalition estimate its contribution to a given project. 


\section{Reported Petroleum Savings}

Coordinators submitted information on their petroleum use reductions, broken down according to the technologies in the Clean Cities portfolio. These activities, along with the outreach functions performed by the AFDC and through ORNL's fuel economy work, comprise the "Core Activities" of the Clean Cities program. To aggregate the coalitions' petroleum use reductions, NREL analyzed the data, converted them into a quantity of gasoline saved by each element of the portfolio, and reported in units of gasoline-gallon equivalents (GGEs) - the amount of energy contained in a gallon of gasoline. As shown in Table 1, about 479 million GGEs (MGGEs) were saved through primary Clean Cities coalition efforts in 2012 - an average of 5.8 MGGEs per coalition. This is 3\% higher than the total 2011 reported petroleum savings of 465 MGGEs.

\section{Alternative Fuels and Vehicles}

As shown in Table 1, alternative fuels (used in AFVs and in biodiesel blends) accounted for 348 MGGE, or $72 \%$ of the coalitions' reported petroleum savings. This is about the same amount of petroleum that was saved by alternative fuels in 2011 .

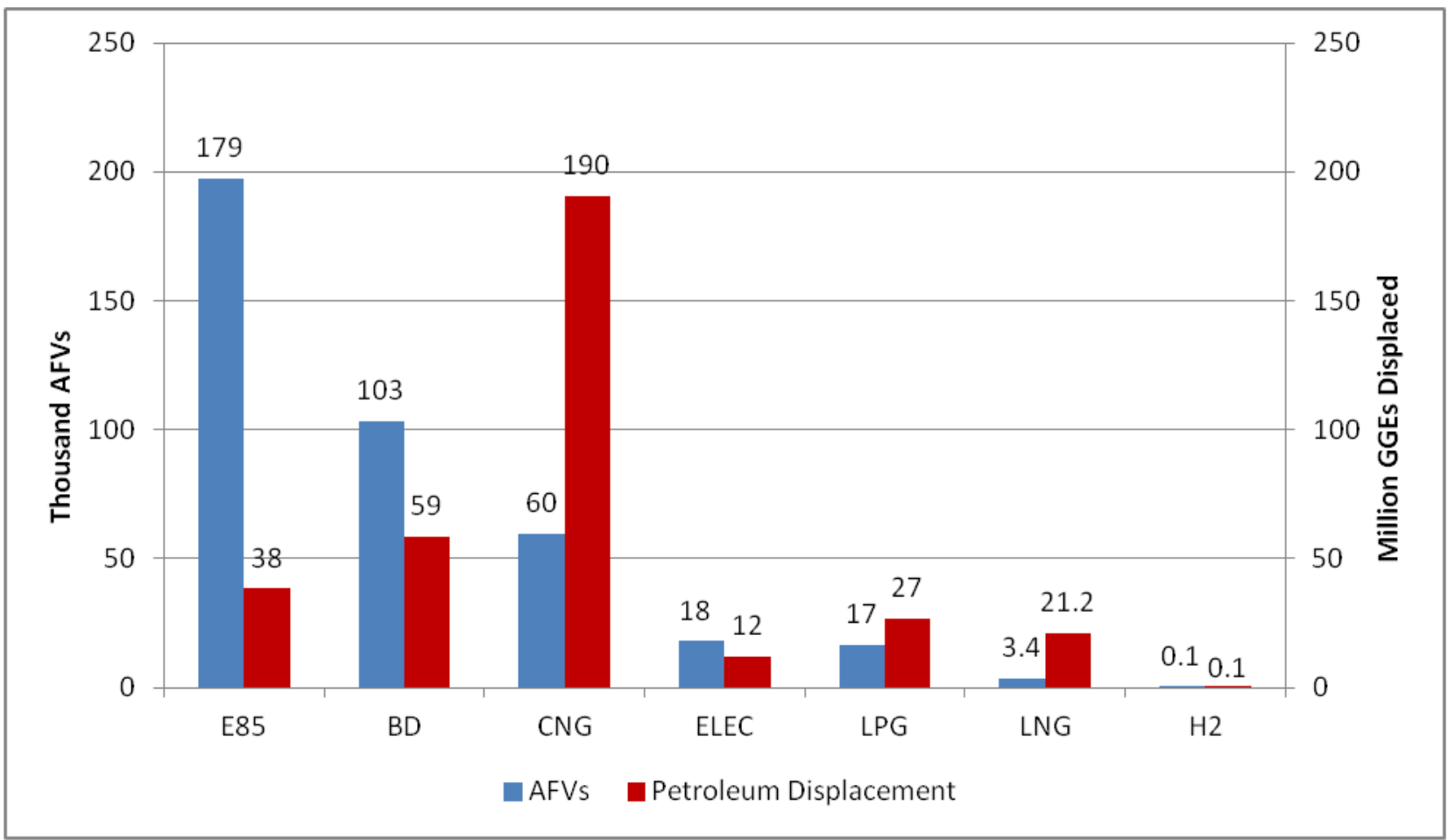

Figure 1. Number of AFVs and petroleum savings from fuel type

In 2012, coalitions reported a total inventory of nearly 400,000 AFVs, split among seven fuel types (Figure 1). This represents a 40\% decrease from last year, largely due to a huge $(283,000)$ reduction in the number of flexible fuel vehicles (FFVs) reported. This reduction emanates from a few large fuel station projects in Tucson, Detroit, and North Dakota that over-estimated the number of FFVs filling at their stations last year. The percentages of AFVs powered by hydrogen, liquefied natural gas (LNG), and liquefied petroleum gas (LPG or propane) also decreased $(58 \%, 21 \%$, and $12 \%$, respectively). Conversely, the percentages of AFVs powered by 
electricity, compressed natural gas $(\mathrm{CNG})$, and biodiesel increased $(78 \%, 24 \%$, and 4\%, respectively).

Figure 1 also shows the total GGEs displaced by AFVs according to fuel type. CNG remains at the top of the list, accounting for $55 \%$ of the total AFV petroleum displacement, despite the fact that only $15 \%$ of the total AFVs use CNG. This is in stark contrast to E85 (a high-level ethanol blend), which accounts for only $11 \%$ of the AFV petroleum savings even though $50 \%$ of reported AFVs can use E85.

The amount of petroleum displaced by AFVs remained level this year despite substantial changes in the use of some fuels. Displacements resulting from propane and CNG use increased $41 \%$ and $14 \%$, respectively. Displacement resulting from hydrogen decreased $50 \%$ due to a decrease in the number (68) of reported vehicles. Displacements resulting from LNG, electricity, E85, and biodiesel each fell between $24 \%$ and 16\%. In the case of electricity, 2012 petroleum displacement dropped largely because we disallowed the inclusion of or reduced the Clean Cities contribution of three very large electric mass transit projects.

The average number of GGEs displaced per vehicle, as shown in Table 2, reveals some interesting trends. For a given vehicle, this number is influenced by four factors:

1. The frequency with which the AFV uses alternative fuel (dedicated AFVs tend to displace more petroleum than vehicles that can use petroleum-based fuels in addition to alternative fuels)

2. The number of miles per year the AFV travels (higher mileage displaces more petroleum)

3. The AFVs' fuel economy (vehicles with lower fuel economy consume more fuel and therefore displace more petroleum)

4. The amount of petroleum contained in the alternative fuel (ethanol and biodiesel blends contain significant quantities).

For example, LNG vehicles captured in the data displace much more petroleum per vehicle on average than do any other AFVs - nearly twice as much as CNG vehicles and more than 30 times as much as FFVs. This is not surprising, given that LNG vehicles are primarily used in heavy-duty applications and travel relatively long distances. In 2012 the average AFV displaced 874 GGEs of petroleum. This is a $66 \%$ increase over last year, indicating that drivers optimized their use of AFVs to reduce petroleum consumption.

Table 2. Average Annual Petroleum Displacement per Vehicle

\begin{tabular}{|l|l|}
\hline Fuel & GGEs Reduced per Vehicle \\
\hline LNG & 6,210 \\
\hline CNG & 3,202 \\
\hline Hydrogen & 2,763 \\
\hline Propane & 1,620 \\
\hline Electricity & 662 \\
\hline Biodiesel & 569 \\
\hline E85 & 195 \\
\hline \hline $\begin{array}{l}\text { Average } \\
\text { (Weighted) }\end{array}$ & 874 \\
\hline
\end{tabular}

This report is available at no cost from the National Renewable Energy Laboratory (NREL) at www.nrel.gov/publications. 
Thirty-one percent of the reported AFVs were heavy-duty vehicles (HDVs) — an increase of 13 percentage points from 2011. The increase is largely due to the aforementioned reduction in reported LDV FFVs. This $31 \%$ of the AFVs is responsible for $75 \%$ of the petroleum savings. The average HDV displaces 6.5 times as much petroleum as the average light-duty vehicle (LDV). The use of LNG is confined exclusively to HDVs. About $85 \%$ of the savings from CNG, biodiesel, and hydrogen comes from HDVs. Seventy to $75 \%$ percent of the petroleum savings from LPG and electricity occurred in HDVs. The only fuel whose use was dominated by LDVs was E85 (with only 2\% used by HDVs).

\section{Hybrid and Plug-In Hybrid Electric Vehicles}

The number of HEVs resulting from Clean Cities efforts almost tripled to 141,000 in 2012, representing about $26 \%$ of the total vehicles (AFVs plus HEVs and PHEVs) reported. The use of these vehicles in place of conventional vehicles saved 40 million GGEs in 2012, for an average of 280 GGEs per HEV.

PHEVs increased from 428 to nearly 2,500 vehicles between 2011 and 2012, reflecting the increased availability of this technology since the Chevrolet Volt went into production. According to coalition-reported data, the average PHEV displaced 351 GGEs of petroleum, which is between 280 GGEs per HEV and 662 GGEs per EV, as we would expect.

\section{Fuel Economy}

Petroleum savings from coalition fuel economy (FE) projects increased 26\% in 2012, to 13.6 MGGEs. This savings resulted from nearly 25,000 vehicles, for an average displacement of 550 GGEs per vehicle. All eight categories displayed in Figure 2, except for "other" and "more efficient vehicle," showed substantially increased displacement over 2011. Figure 2 shows that some FE improvement projects were much more effective at reducing petroleum than others.

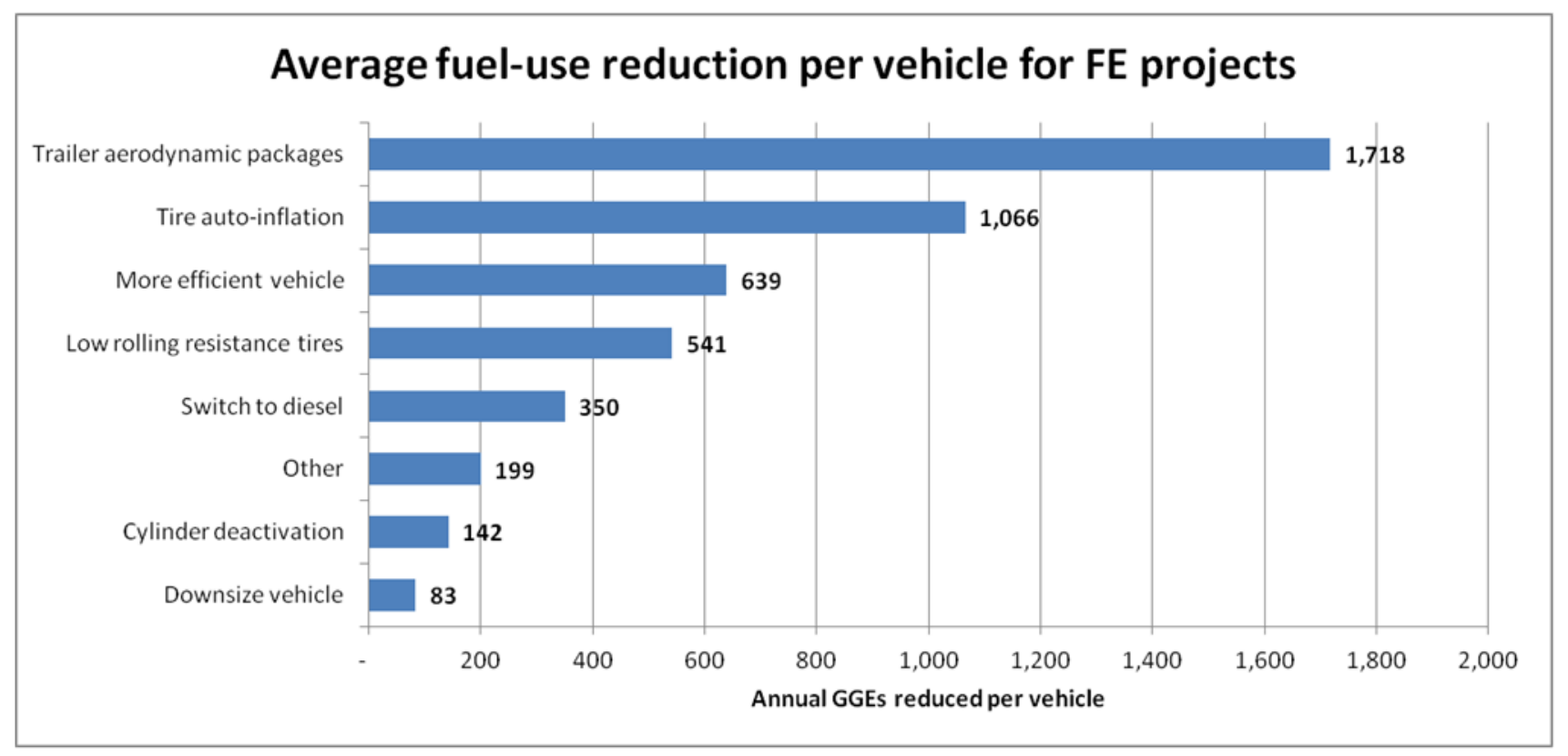

Figure 2. Average fuel-use reduction per vehicle for 2012 fuel economy projects 


\section{VMT Reduction}

VMT reduction projects save fuel by reducing the miles that vehicles travel. They include strategies such as carpooling, biking, telework, and public transportation. Eighty percent of the coalitions reported at least one VMT reduction project in 2012-up from 55\% in 2011. The total number of projects increased $25 \%$ in 2012 and their cumulative displacement increased $17 \%$. Details of the project types, number, and size are shown below in Table 3.

Table 3. VMT Reduction Project Types, Number, and Displacement

\begin{tabular}{|l|l|l|l|l|}
\hline Project Type & $\begin{array}{l}\text { Number of } \\
\text { Projects }\end{array}$ & $\begin{array}{l}\text { Increase in Number } \\
\text { of Projects }\end{array}$ & $\begin{array}{l}\text { Total GGE } \\
\text { Reduced }\end{array}$ & $\begin{array}{l}\text { GGEs per } \\
\text { Project }\end{array}$ \\
\hline Other & 78 & 26 & $5,423,535$ & 69,532 \\
\hline Carpooling & 65 & 10 & $19,659,083$ & 302,447 \\
\hline Mass Transit & 52 & -1 & $13,811,978$ & 265,615 \\
\hline $\begin{array}{l}\text { Non-Motorized } \\
\text { Locomotion }\end{array}$ & 39 & 12 & 354,070 & 9,079 \\
\hline Telecommute & 21 & 1 & 275,617 & 13,125 \\
\hline Car Share & 19 & 7 & 768,431 & 40,444 \\
\hline Alt. Work Schedule & 3 & 3 & 19,850 & 6,617 \\
\hline TOTAL & 277 & 58 & $40,312,563$ & 145,533 \\
\hline
\end{tabular}

\section{Idle Reduction}

Idle-reduction (IR) strategies include truck-stop electrification (TSE), onboard IR, and IR policies. Estimated fuel savings for IR technologies and policies was 31.1 MGGEs in 2012. While the overall petroleum reduction from IR projects remained relatively even, there was a shift toward a larger number of smaller projects. Furthermore, there was a shift from onboard IR toward TSE and IR policies. As shown in Figure 3, IR policies accounted for $50 \%$ of the savings estimated for the three approaches, onboard IR technologies accounted for $39 \%$, and TSE accounted for $9 \%$. 


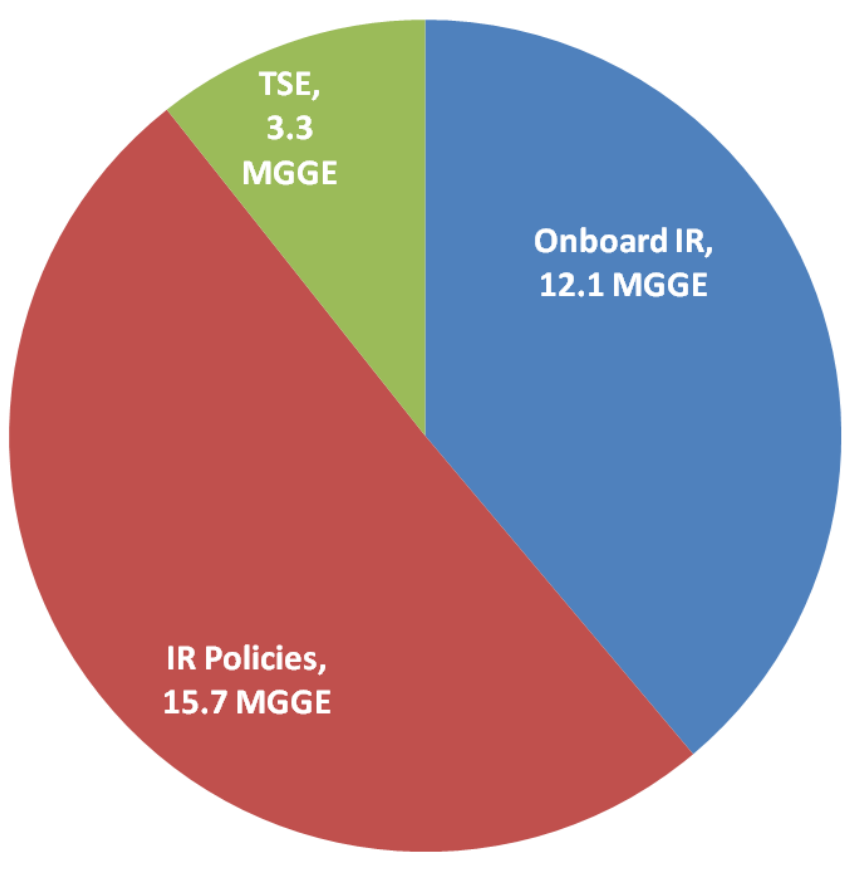

Figure 3. Fuel savings from idle-reduction projects

\section{Estimated Petroleum Savings}

Estimated petroleum savings comprise two categories: "estimated lab savings," which includes national lab activities, such as the Fuel Economy Guide and the AFDC website; and "estimated coalition outreach savings," which includes coalition outreach activities. Both of these categories impact behaviors such as vehicle purchases, fuel choice, driving habits, vehicle maintenance, and transportation patterns. Calculating these petroleum savings involves a fair degree of uncertainty, but it is nevertheless important to quantify the impacts of educational and outreach activities as best we can. This section outlines our approach and provides the results.

\section{Methods Used to Estimate Petroleum Use Reduction by Websites and Outreach Activities}

2012 is the fourth year for which petroleum use reduction was attributed to the program's online information resources and to outreach events held by Clean Cities coalitions. To quantify these estimated savings, NREL and ORNL developed the Petroleum Impact Model (PIM) and NREL added related functionality to the Clean Cities annual report website.

Clean Cities coordinators reported the type of outreach event, the number of people reached by each event, the technologies presented, and the coalition's percent attribution. To determine the number of people reached by a given event, the annual report website multiplied the audience number by the percent attributed to the coalition. When multiple technologies were presented in a given event, the annual report website assumed the people reached to be divided evenly among 
the technologies. This data is then entered into the PIM as the "persons reached by the coalition about a given technology."

The PIM multiplies this persons-reached number by the probability they will take action (defined as purchasing an AFV or more efficient vehicle, or as changing driving or fueling behavior). This probability is derived by comparing the outreach event and technology to comparable marketing media and products. Eleven of these media-product combinations have a "customer conversion ratio" that is recorded by various marketing firms, as shown in Table 4. The customer conversion ratio is the ratio of purchases made (desired action) over the total number of people contacted through the outreach activity. The code in Table 4 is provided for continuity through the calculation process.

Table 4. Benchmark Customer Conversion Rates and Their Sources

\begin{tabular}{|l|l|l|}
\hline Code & \multicolumn{1}{|c|}{ Benchmark Conversion Rate } & \multicolumn{1}{c|}{ Reference } \\
\hline 1 & $\begin{array}{l}0.6 \% \text { for electronics (expensive, } \\
\text { complicated) websites }\end{array}$ & Fireclick.com. Accessed June 16, 2011 \\
\hline 2 & $\begin{array}{l}1.3 \% \text { for environmentally related, } \\
\text { incremental cost purchase }\end{array}$ & $\begin{array}{l}\text { Bird, Lori. 2004. Utility Green Pricing Programs: } \\
\text { Design, Implementation, and Consumer Response }\end{array}$ \\
\hline 3 & $2 \%$ for common websites & Fireclick.com. Accessed June 16, 2011 \\
\hline 4 & $2.5 \%$ for industry-specific mail & Direct Marketing Association (DMA). 2011 \\
\hline 5 & $3.2 \%$ for email & Fireclick.com. Accessed June 16, 2011 \\
\hline 6 & $7 \%$ for affiliates & Fireclick.com. Accessed June 16, 2011 \\
\hline 7 & $\begin{array}{l}\text { (Rate not listed here due to copyright } \\
\text { restrictions) AdMeasure product: LDVs }\end{array}$ & GfK Mediamark Research \& Intelligence, LLC. 2011 \\
\hline 8 & $\begin{array}{l}\text { (Rate not listed here due to copyright } \\
\text { restrictions) AdMeasure product: }\end{array}$ & GfK Mediamark Research \& Intelligence, LLC. 2011 \\
\hline 9 & $\begin{array}{l}\text { Gasoline } \\
\text { restrictions) AdMeasure smoking } \\
\text { cessation }\end{array}$ & GfK Mediamark Research \& Intelligence, LLC. 2011 \\
\hline 10 & $2 \%$ for direct mail to current customers & $\begin{array}{l}\text { Eisenberg, B. “The Average Conversion Rate: Is it a } \\
\text { Myth?" ClickZ. February 1, 2008 }\end{array}$ \\
\hline
\end{tabular}

For activity-type/audience-action combinations that weren't directly addressed by research, NREL adjusted the customer conversion ratios based on the Ostrow Model of Effective Frequency, Krugman's Three Exposure Theory, and the author's assumptions. Table 5 lists a set of relationships that increase or decrease the impact of advertisements. 
Table 5. Relationships for Media Effectiveness and Their Sources

\begin{tabular}{|l|l|l|}
\hline Code & \multicolumn{1}{|c|}{ Relationships } & \multicolumn{1}{|c|}{ Source } \\
\hline A & Degree of media interactivity increases impact & Ostrow Model of Effective Frequency \\
\hline B & Brand recognition increases impact & Ostrow Model of Effective Frequency \\
\hline C & Long purchase cycle increases impact & Ostrow Model of Effective Frequency \\
\hline D & Less frequent usage of item increases impact & Ostrow Model of Effective Frequency \\
\hline E & Affordability of item increases impact & Ostrow Model of Effective Frequency \\
\hline F & Simple message increases impact & Ostrow Model of Effective Frequency \\
\hline G & Media clarity (not cluttered) increases impact & Ostrow Model of Effective Frequency \\
\hline H & Message in relevant environment increases impact & Ostrow Model of Effective Frequency \\
\hline I & Audience attentiveness increases impact & Ostrow Model of Effective Frequency \\
\hline J & More steps in processing the media increases impact & Krugman's Three Exposure Theory \\
\hline K & Availability of item increases impact & Author's assumption \\
\hline L & Length of vigilance required decreases impact & Author's assumption \\
\hline
\end{tabular}

We adjusted the benchmark conversion rates shown in Table 4 by the relationships for media effectiveness shown in Table 5. The direct application of these rates and relationships is shown in Table 6, where the number relates to the code in Table 4, and the letters relate to the code in Table 5. The final customer conversion ratios used are displayed in Table 7.

Table 6. Combination of Benchmarks and Relationships

\begin{tabular}{|c|c|c|c|c|c|c|c|c|c|}
\hline Activity Type & $\begin{array}{l}3 \\
0 \\
2 \\
0 \\
0 \\
0 \\
\frac{1}{0} \\
0 \\
\frac{1}{3} \\
0 \\
0\end{array}$ & 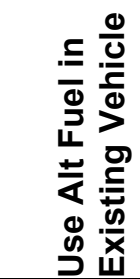 & 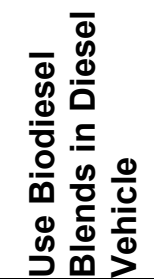 & 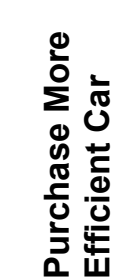 & 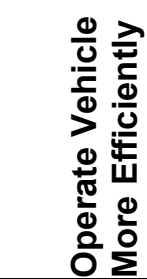 & 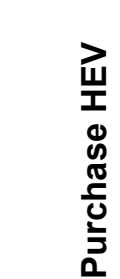 & 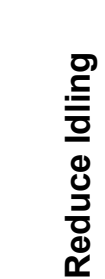 & 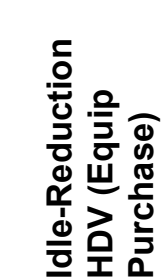 & 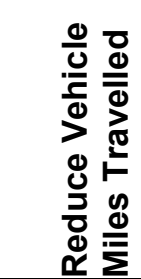 \\
\hline $\begin{array}{l}\text { Advancing the } \\
\text { Choice }\end{array}$ & $\begin{array}{l}6+\mathrm{H}+1+ \\
\mathrm{J}-\mathrm{E}\end{array}$ & $6+\mathrm{H}+\mathrm{I}+\mathrm{J}$ & $6+\mathrm{H}+1+\mathrm{J}$ & $\begin{array}{l}6+\mathrm{H}+\mathrm{I+} \\
\mathrm{J} \\
\end{array}$ & $6+\mathrm{H}+1+\mathrm{J}$ & $\begin{array}{l}6+\mathrm{H}+\mathrm{I+} \\
\mathrm{J}-\mathrm{E} \\
\end{array}$ & 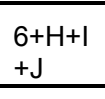 & $6+\mathrm{H}+1+\mathrm{J}-\mathrm{E}$ & $6+\mathrm{H}+\mathrm{I}+\mathrm{J}$ \\
\hline Advertisement & $7-K$ & $8-K-L$ & $8-K-L$ & $7+E$ & 9-G-L & $7-K$ & 9-L & $7+E$ & 9-L \\
\hline Conference & $\begin{array}{l}6+\mathrm{H}+\mathrm{J}- \\
\mathrm{E}\end{array}$ & $6+\mathrm{H}+\mathrm{J}$ & $6+\mathrm{H}+\mathrm{J}$ & $6+\mathrm{H}+\mathrm{J}$ & $6+\mathrm{H}+\mathrm{J}$ & $\begin{array}{l}\text { 6+H+J- } \\
\mathrm{E}\end{array}$ & $6+\mathrm{H}+\mathrm{J}$ & $6+\mathrm{H}+\mathrm{J}-\mathrm{E}$ & $6+\mathrm{H}+\mathrm{J}$ \\
\hline $\begin{array}{l}\text { Literature } \\
\text { Distribution }\end{array}$ & $\begin{array}{l}4+\mathrm{B}+\mathrm{H}- \\
\mathrm{E}\end{array}$ & $4+B+H$ & $4+B+H$ & $4+B+H$ & $4+B+H$ & $\begin{array}{l}4+\mathrm{B}+\mathrm{H}- \\
\mathrm{E}\end{array}$ & $4+B+H$ & $4+B+H-E$ & $4+B+H$ \\
\hline Media Event & $\begin{array}{l}\text { 7-E-G- } \\
\text { H-K }\end{array}$ & 8-G-H-K & 8-G-H-K & $\begin{array}{l}7-G- \\
H+E-K\end{array}$ & 9-G-H-K & $\begin{array}{l}\text { 7-E-G-G- } \\
\mathrm{H}+\mathrm{B}-\mathrm{K}\end{array}$ & $\begin{array}{l}9-\mathrm{G}-\mathrm{H}- \\
\mathrm{K}\end{array}$ & 7-E-G-H-K & 9-G-H-K \\
\hline Meeting & $\begin{array}{l}6+A+B+ \\
l-E\end{array}$ & $6+A+B+1$ & $6+A+B+1$ & $\begin{array}{l}6+A+B+ \\
1 \\
\end{array}$ & $6+A+B+1$ & $\begin{array}{l}6+A+B+ \\
\text { I-E } \\
\end{array}$ & $\begin{array}{l}6+A+B \\
+1 \\
\end{array}$ & $6+A+B+1-E$ & $6+A+B+1$ \\
\hline Website & $1+B+J$ & $3+B+J$ & $3+B+J$ & $3+B+J$ & $3+B+J$ & $1+B+J$ & $3+B+J$ & $1+B+J$ & $3+B+J$ \\
\hline
\end{tabular}


Table 7. Customer Conversion Ratios Used in the PIM

\begin{tabular}{|c|c|c|c|c|c|c|c|c|c|}
\hline Activity Type & 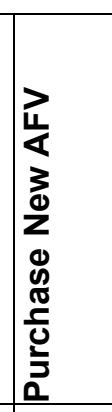 & 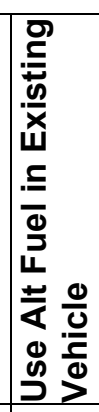 & 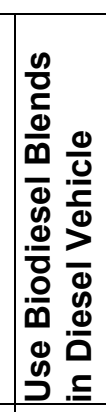 & 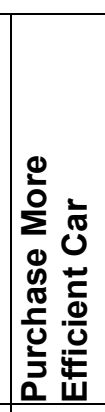 & 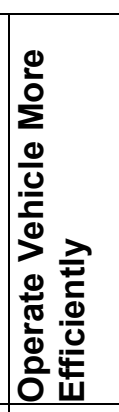 & 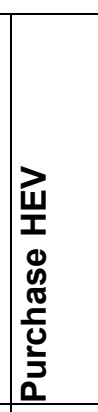 & 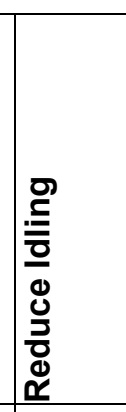 &  & 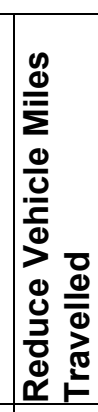 \\
\hline Advancing the Choice & $2.0 \%$ & $6.0 \%$ & $6.0 \%$ & $5.0 \%$ & $7.0 \%$ & $2.0 \%$ & $5.0 \%$ & $4.0 \%$ & $8.0 \%$ \\
\hline Advertisement & $0.6 \%$ & $5.5 \%$ & $5.5 \%$ & $2.0 \%$ & $10.0 \%$ & $2.0 \%$ & $10.0 \%$ & $3.0 \%$ & $4.0 \%$ \\
\hline Conference & $2.0 \%$ & $6.0 \%$ & $6.0 \%$ & $5.0 \%$ & $7.0 \%$ & $2.0 \%$ & $5.0 \%$ & $4.0 \%$ & $8.0 \%$ \\
\hline Literature Distribution & $2.0 \%$ & $3.0 \%$ & $3.0 \%$ & $2.5 \%$ & $3.0 \%$ & $2.5 \%$ & $3.0 \%$ & $2.5 \%$ & $5.0 \%$ \\
\hline Media Event & $0.3 \%$ & $2.0 \%$ & $2.5 \%$ & $1.0 \%$ & $3.0 \%$ & $1.0 \%$ & $4.0 \%$ & $1.5 \%$ & $1.5 \%$ \\
\hline Meeting - Other & $2.0 \%$ & $7.0 \%$ & $6.0 \%$ & $5.0 \%$ & $7.0 \%$ & $2.0 \%$ & $5.0 \%$ & $4.0 \%$ & $8.0 \%$ \\
\hline Website & $2.0 \%$ & $4.0 \%$ & $3.0 \%$ & $3.0 \%$ & $4.0 \%$ & $3.0 \%$ & $3.0 \%$ & $3.0 \%$ & $3.0 \%$ \\
\hline
\end{tabular}

The persons-reached multiplied by the appropriate customer conversion ratio (from Table 7) results in the number of people assumed to take the intended action. At this point, the PIM is similar to the Clean Cities annual reporting tool, as it converts the estimated number of vehicles purchased or number of people changing their driving habits into reduced petroleum use. We make downward adjustments to the estimates to account for probable overlaps between audiences attending outreach events and entities reporting their own petroleum savings via a Clean Cities coalition. We only apply the estimated petroleum savings to the reporting year in question, even though many of the vehicle purchases and behavioral changes will likely last beyond that year.

We also used the PIM to estimate petroleum savings resulting from the AFDC. NREL gathers AFDC website statistics that allow us to estimate the number and characteristics of individual users. The PIM then uses inputs, defaults, and methodologies similar to those it employs in calculating the savings from coalition websites (including the website row of Table 4) to estimate the total petroleum savings attributable to the AFDC.

\section{Estimated Lab Savings}

Both NREL and ORNL use a variety of means to track the use of the information and resources they provide on behalf of the Clean Cities program. ORNL produces the Fuel Economy Guide based on fuel economy data from the Environmental Protection Agency. It also produces and maintains the FuelEconomy.gov website along with other print products and educational activities related to fuel economy. By tracking the number of new car buyers, used car buyers, and car drivers exposed to fuel economy products through their educational materials, and assuming a $1 \%-3.3 \%$ improvement in fuel economy per customer, ORNL estimated that the fuel economy materials resulted in a savings of 177 MGGE in 2012.

Online resources managed by NREL reached a large audience in 2012: the Clean Cities and AFDC websites received a combined 5.9 million page views. The sites provide a range of 
resources to support coordinators, fleets, businesses, policymakers, and other transportation decision-makers in their efforts to implement the technologies and strategies in the Clean Cities portfolio. The sites' content includes technical data, case studies, publications, and industry contacts, along with databases of federal and state incentives and laws, fueling station locations, available vehicles, and other information and tools.

NREL estimates that the 5.5 million page views through 1.4 million visits by 1.0 million users of the AFDC resulted in a petroleum savings of 69 MGGEs in 2012. The AFDC engaged the average visitor for 3.5 minutes. The Clean Cities website received 400,000 page views through 136,000 visits from 69,000 visitors, and held the average visitor for more than 3 minutes. We assumed that $20 \%$ of the AFDC visitors were overlaps with activities reported by the coalitions. We did not make petroleum use reduction estimates for the Clean Cities website, because we assume the majority of site visits are related to Clean Cities activities taking place through coalitions, and those activities are already reported by the coalitions. For the same reason, we did not make petroleum use reduction estimates for other Clean Cities activities performed by NREL, such as webinars, technical advice, presenting and exhibiting at conferences, and publications.

\section{Estimated Coalition Outreach Savings}

We classified coalitions' outreach, education, and training activities into nine categories, as shown in Table 8. A total of 2,338 activities were reported, and these activities were estimated to reach over 100 million people. Compared to 2011, the number of events increased $3 \%$, while the number of persons reached increased $8 \%$. This is because the average size of events increased slightly from last year-from 44,457 persons per event to 46,428. The majority of people (51\%) were reached through media events in 2012 , even though only $14 \%$ of the outreach activities were media events. Meetings were the most common type of outreach event (33\%), but only reached $0.5 \%$ of the outreach audience. There was an extremely large (80-fold) increase in the number of people reached by social media in 2012. It should be noted that the "Advancing the Choice" category was changed to "workshop" in 2012. Also, a few media events promoting E15 (a low-level ethanol blend) were held, but were not counted in the estimated outreach savings since their efficacy is not known.

Table 8. Outreach, Education, and Training Activities

\begin{tabular}{|l|l|l|l|l|}
\hline Activity Type & $\begin{array}{l}\text { Persons } \\
\text { Reached }\end{array}$ & $\begin{array}{l}\text { Share of Total } \\
\text { Persons Reached }\end{array}$ & $\begin{array}{l}\text { Number of } \\
\text { Activities }\end{array}$ & $\begin{array}{l}\text { Share of } \\
\text { Total } \\
\text { Activities }\end{array}$ \\
\hline Media Event & $54,963,067$ & $50.6 \%$ & 329 & $14.1 \%$ \\
\hline Advertisement & $48,222,469$ & $44.4 \%$ & 25 & $1.1 \%$ \\
\hline Literature Distribution & $1,360,354$ & $1.3 \%$ & 219 & $9.4 \%$ \\
\hline Conference Participation & $1,239,392$ & $1.1 \%$ & 382 & $16.3 \%$ \\
\hline Website & 911,612 & $0.8 \%$ & 29 & $1.2 \%$ \\
\hline Social Media & 531,788 & $0.5 \%$ & 35 & $1.5 \%$ \\
\hline Meeting - Other & 502,510 & $0.5 \%$ & 763 & $32.6 \%$ \\
\hline Workshop & 773,191 & $0.7 \%$ & 248 & $10.6 \%$ \\
\hline Meeting - Stakeholder & 44,707 & $0.0 \%$ & 308 & $13.2 \%$ \\
\hline \hline TOTAL & $108,549,090$ & $100.0 \%$ & 2,338 & $100.0 \%$ \\
\hline
\end{tabular}


Figure 4 illustrates the types of audiences of the 2,338 outreach activities. Any one activity could be aimed at more than one audience; in fact, each activity targeted an average of 3.5 different audiences. The general public was the most-cited target audience, followed by government fleets, then private fleets. Entities with specialized applications- utility trucks, mass transit, delivery trucks, waste management, and airports — were identified as audiences in nearly $38 \%$ of the outreach activities.

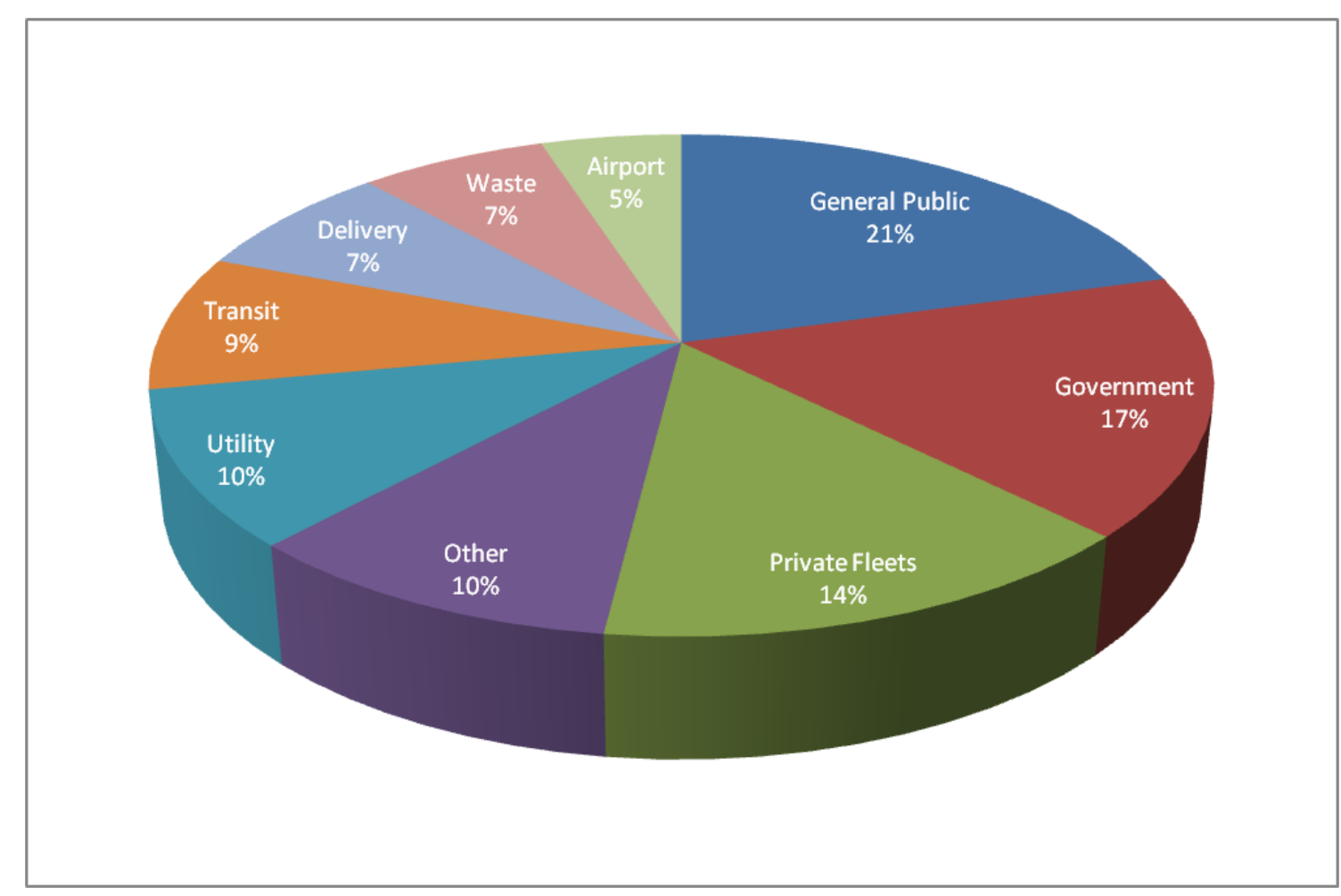

Figure 4. Percent of outreach activities split among audience types

The coalitions' outreach events featured a relatively even mix of technologies, as illustrated in Figure 5. No single technology dominated, but AFVs were covered more than any of the other technology types. AFVs' share of overall outreach events increased from $29 \%$ to $32 \%$ in 2012 . All other activities kept the same share, except for a 1\% reductions in fuel economy, fuel blends, and VMT reduction activities. Just as with audience types, any one activity could be centered on more than one technology; in fact, each activity featured an average of 2.7 different technologies. 


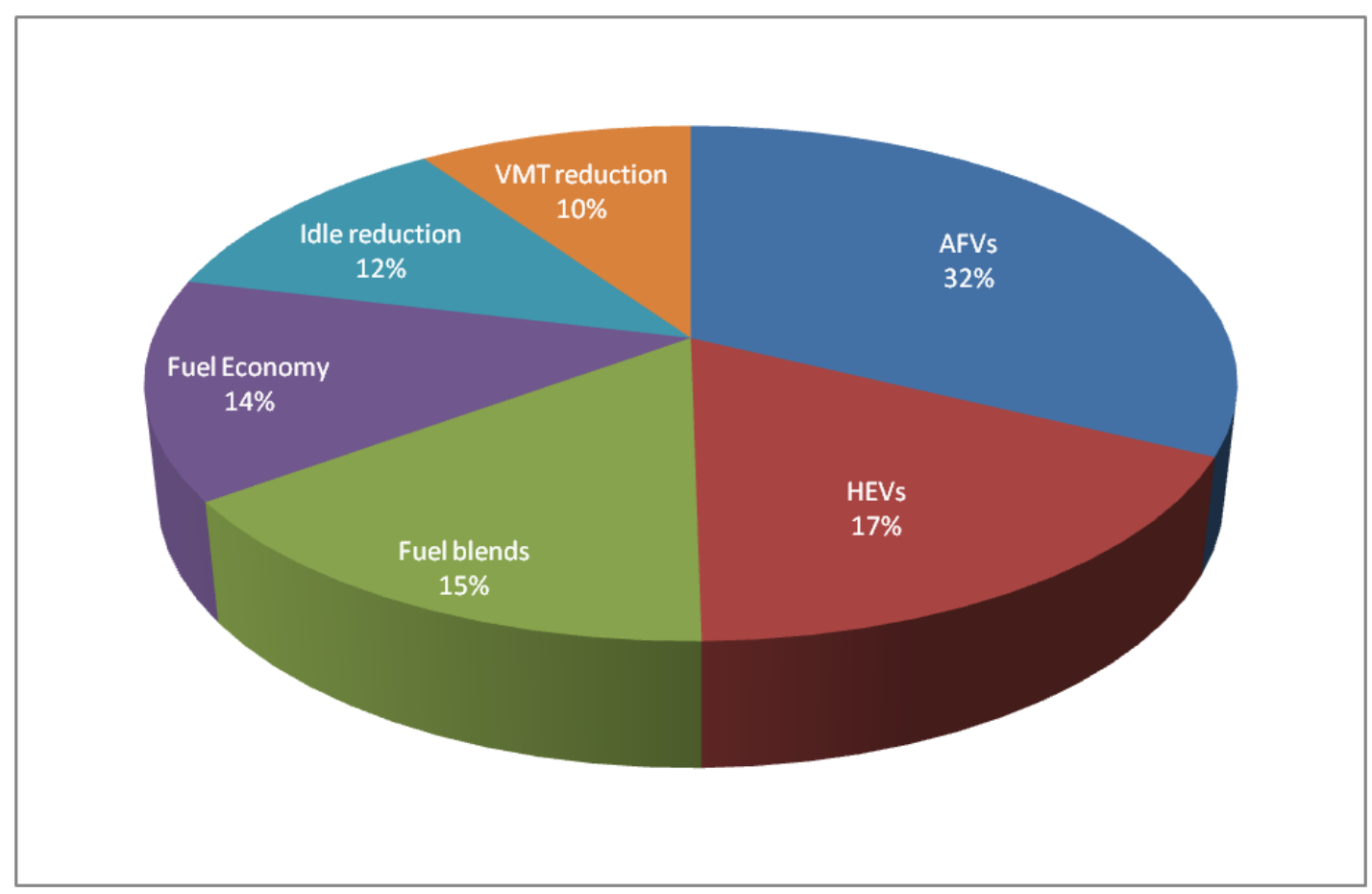

Figure 5. Percent of outreach activities by technology type

Using the PIM, NREL estimates that Clean Cities coalition outreach events prompted and enabled actions that saved 182 MGGEs of petroleum in 2012.

\section{Goal Tracking}

In 2005, Clean Cities set a goal of displacing 2.5 billion GGEs per year by 2020. The data presented in this report show that Clean Cities is ahead of schedule to meet this goal. Clean Cities' progress toward its petroleum use reduction goal is shown in Figure 6, where the path toward achieving the 2020 goal is represented by the blue dashed line, and actual petroleum savings are tracked by the black solid line. When the goal was originally set in 2005 , meeting it required a compounded annual growth rate of $16.6 \%$. However, because of higher-than-projected petroleum savings in subsequent years, the average growth rate required henceforth to meet the 2020 goal is $13.5 \%$. 


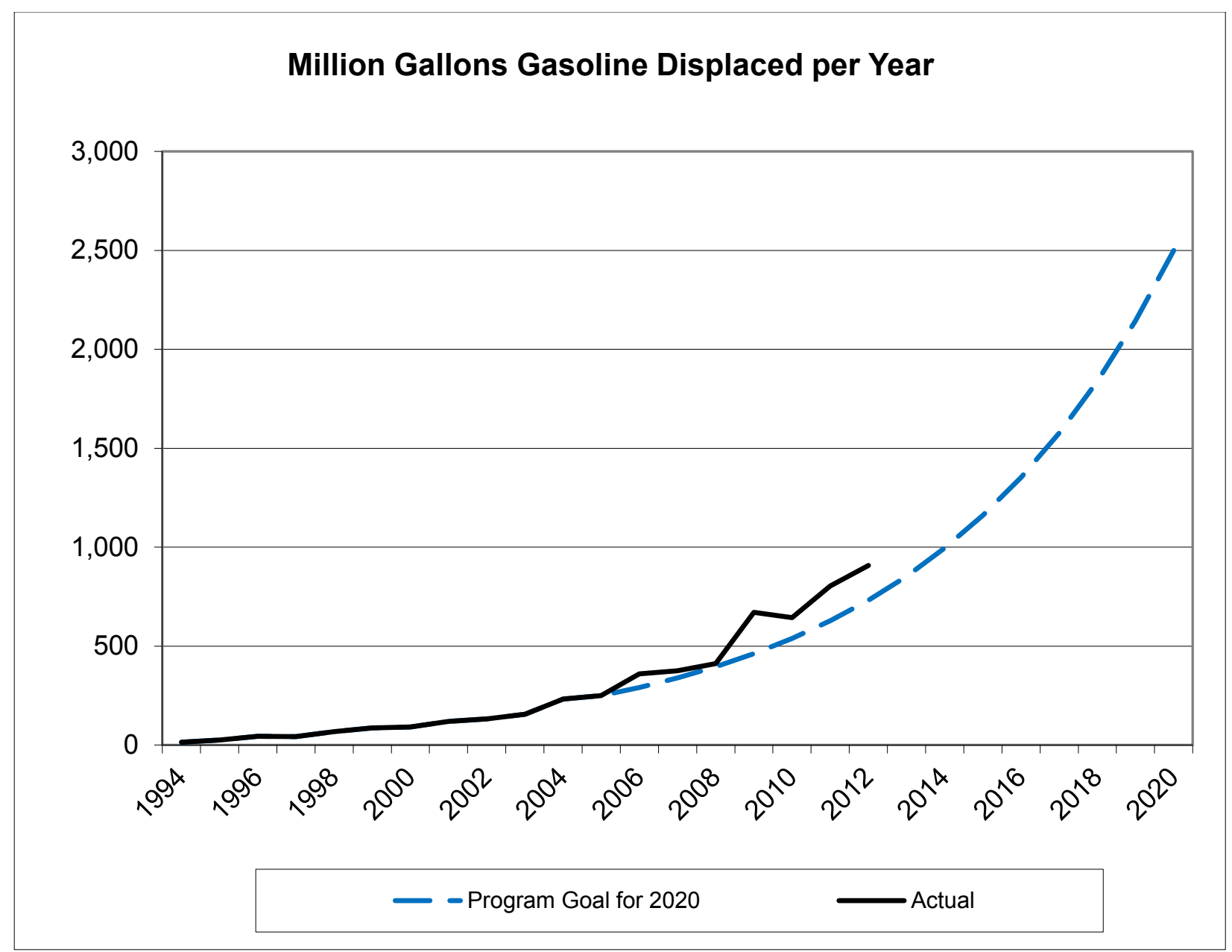

Figure 6. Annual petroleum savings trajectory to meet 2020 goal and actual progress

\section{Greenhouse Gas Emissions Reduction}

Clean Cities' petroleum use reduction leads to a substantial reduction in GHG emissions, the pollutants responsible for global climate change. To estimate the GHG reductions resulting from Clean Cities activities, we used a variation of Argonne National Laboratory's Greenhouse Gas, Regulated Emissions, and Energy Use in Transportation (GREET) model. This model takes into account the fuel life cycle, or "well to wheels," GHG emissions for transportation fuels, which include fuel production, transport, and use in the vehicle. It does not take into account the emissions from indirect land use changes or vehicle manufacturing. Table 9 lists Clean Cities 2012 GHG emissions reductions by technology type. The table also indicates the number of passenger cars that would need to be removed from the road to achieve an equivalent reduction in GHG emissions. 
Table 9. GHG Emissions Reduced by Clean Cities in 2012

\begin{tabular}{|l|l|l|l|}
\hline & $\begin{array}{l}\text { Tons of GHG } \\
\text { Emissions Averted }\end{array}$ & $\begin{array}{l}\text { Equivalent } \\
\text { Cars } \\
\text { Removed }\end{array}$ & $\begin{array}{l}\text { Percent of } \\
\text { Coalition } \\
\text { Total }\end{array}$ \\
\hline Alt Fuels \& Vehicles & $1,115,737$ & 245,217 & $41 \%$ \\
\hline VMT Reduction & 496,845 & 109,197 & $18 \%$ \\
\hline HEVs and PHEVs & 492,226 & 108,182 & $18 \%$ \\
\hline Idle Reduction & 378,626 & 83,214 & $14 \%$ \\
\hline FE Improvements & 167,932 & 36,908 & $6 \%$ \\
\hline Off-Road Vehicles & 48,140 & 10,580 & $2 \%$ \\
\hline Coalition Reported Total & $2,699,506$ & 593,298 & $100 \%$ \\
\hline ORNL Fuel Economy & $2,177,763$ & 478,629 & na \\
\hline AFDC & 193,662 & 42,563 & na \\
\hline Outreach Events & $1,565,668$ & 344,103 & na \\
\hline Grand Total & $6,636,598$ & $1,458,593$ & na \\
\hline
\end{tabular}

* Calculated as total passenger car GHG emissions (Table 2-15 in the EPA's 2012 Inventory of GHG Emissions and Sinks) divided by total short wheelbase LDVs (Table VM-1 in the Federal Highway Administration's Highway Statistics, 2010)

Alternative fuels and vehicles were responsible for more GHG emissions reductions than any other coalition-reported activity. We calculated these reductions by subtracting the life cycle GHG emissions resulting from the use of an alternative fuel in a vehicle from the life cycle GHG emissions resulting from the use of gasoline or diesel fuel in an equivalent vehicle. For the purposes of these calculations, gasoline is considered the baseline fuel for all LDVs, except in the case of biodiesel, for which conventional diesel fuel is used as the baseline. Gasoline is considered the baseline fuel for HDVs using E85, CNG, LNG, and LPG, because these vehicles are equipped with spark-ignition (gasoline-like) engines. For all other alternative fuel HDVs, we used conventional diesel fuel as the baseline. Figure 7 shows which fuels were used to achieve these reductions and how many AFVs were required for a given reduction. Notably, the GHG emissions reductions are not necessarily proportional to the petroleum displacement shown in Figure 1, because the various alternative fuels emit different levels of life cycle GHGs. It is also worth noting that VMT reduction, HEVs, idle reduction, and fuel economy improvement projects have a disproportionately high reduction of GHGs relative to their petroleum displacement. This is because these technologies eliminate $100 \%$ of the GHG emissions per gallon of petroleum saved, while alternative fuels reduce GHG emissions by a lesser amount per gallon of petroleum saved. 


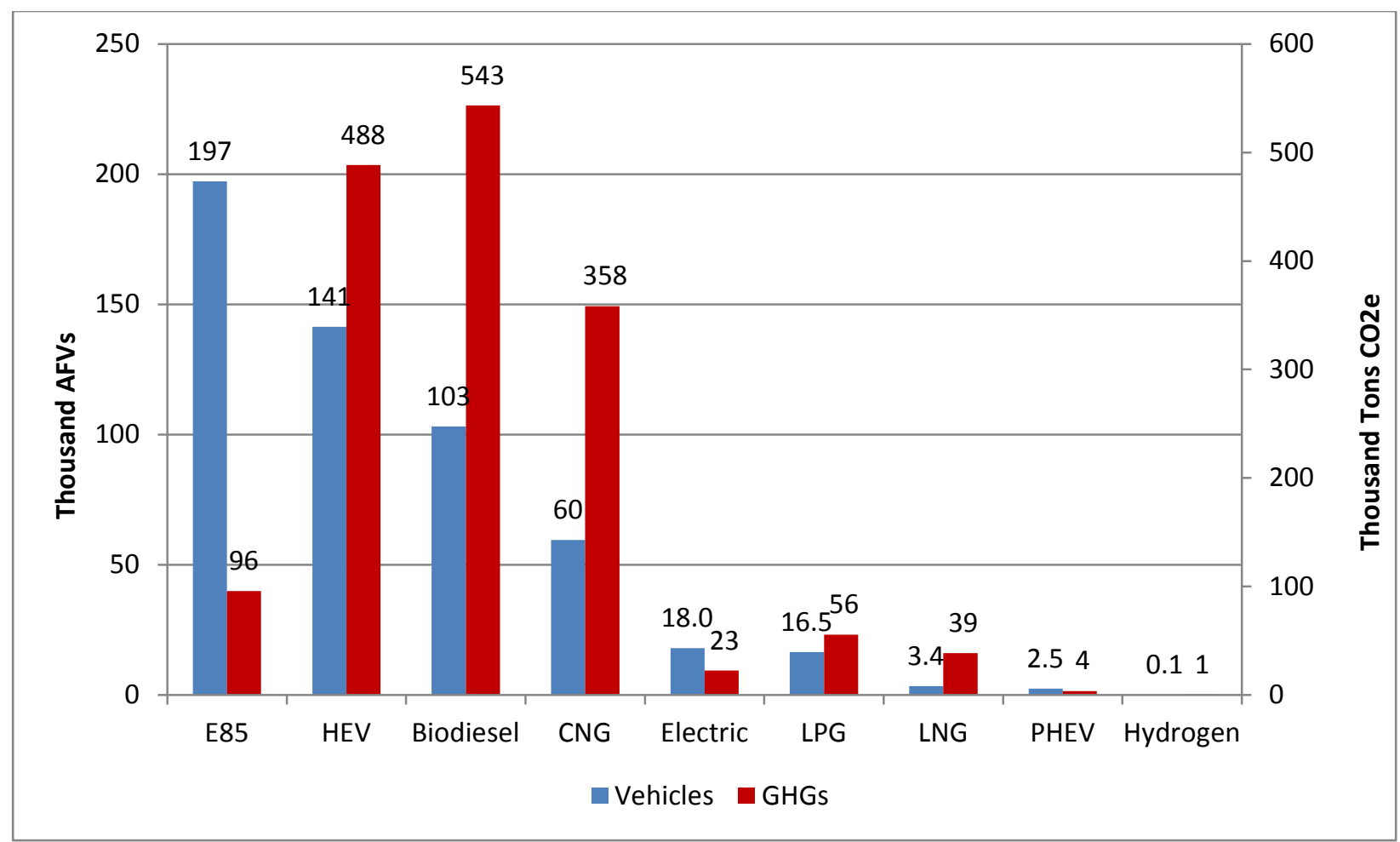

Figure 7. Number of AFVs and amount of GHG reduction by fuel type

\section{Off-Road Vehicles}

Alternative fuels are used in off-road applications as well as on-road applications. Table 10 shows the number of AFVs (or pieces of equipment) reported by coalitions in 2012. These categories are self-descriptive, with the exceptions of "construction equipment," which includes cranes, earth movers, and similar equipment; and "recreation equipment," which includes jet skis, snowmobiles, and all-terrain vehicles. The number of alternative fuel off-road vehicles decreased 3\% from 2011 to 2012, yet their overall petroleum displacement increased 15\%. This was likely because the number of vehicles declined in applications that use smaller quantities of fuel (e.g., forklifts, landscaping equipment, and recreational equipment) while the number of vehicles increased in applications that use large quantities of fuel (e.g., construction, farm equipment, planes, and railroad). Biodiesel use accounted for $62 \%$ of the AFVs included in this category. Other fuels used in off-road applications included LPG (18\%) and electricity (14\%). The other six fuels and technologies together accounted for less than $6 \%$ of the total; no E85 was used in off-road equipment in 2012.

Coordinators reported alternative fuel consumption in these vehicles, which the reporting website converted into petroleum savings. Overall savings from off-road vehicles totaled 6.6 MGGE. The most commonly reported fuel-application combinations included biodiesel construction equipment, biodiesel mining equipment, LPG forklifts, and electric forklifts. The various applications varied widely in the number of GGEs displaced per vehicle, as shown in Table 10. 
Table 10. Number of Off-Road Vehicles or Equipment and Petroleum Saved

\begin{tabular}{|l|l|l|l|}
\hline Application & $\begin{array}{l}\text { Number of } \\
\text { Vehicles }\end{array}$ & GGE Saved & $\begin{array}{l}\text { GGEs per } \\
\text { Vehicle }\end{array}$ \\
\hline Construction Equipment & 5,211 & 668,328 & 3,108 \\
\hline Other & 4,475 & $1,005,176$ & 4,389 \\
\hline Forklifts & 2,159 & 574,705 & 1,172 \\
\hline Mining Equipment & 1,411 & $2,702,084$ & 24,761 \\
\hline Landscaping Equipment & 1,245 & 234,587 & 1,421 \\
\hline Recreational Equipment & 397 & 22,610 & 45 \\
\hline Farm Equipment & 84 & 162,424 & 402 \\
\hline Ships & 36 & 999,860 & 10,618 \\
\hline Street Sweeper & 32 & 31,480 & 62 \\
\hline Planes & 20 & 3,242 & 11 \\
\hline Railroads & 14 & 217,642 & 2,149 \\
\hline TOTAL & 15,084 & $6,622,138$ & 48,140 \\
\hline
\end{tabular}

\section{AFV Types and Markets}

The online reporting tool asked coordinators to categorize their AFVs into key vehicle types and niche market fleets. Table 11 shows that the largest portion (39\%) of AFVs are cars. Light trucks/vans/SUVs comprise the second-largest category, which accounts for $22 \%$ of the AFVs. "Unknown" or "other" light-duty vehicles were the third most numerous AFV (at 11\% of total). Most of these use E85 and were reported in conjunction with a public refueling station. "Unknown" or "other" heavy-duty vehicles, which were mostly reported in conjunction with biodiesel public refueling stations, accounted for $10 \%$ of the vehicles. Heavy trucks without trailers comprised $7 \%$ of the AFVs, and none of the remaining categories surpassed $4 \%$ of the vehicle population.

The most popular fuel/vehicle combination was HEV cars (with 124,000 HEVs), followed by E85 light trucks/vans/SUVs $(89,000)$. The combinations that have grown the most since 2011 are E85 delivery trucks, biodiesel semi-trucks, CNG refuse trucks, electric cars, and electric delivery trucks. Patrol cars using CNG, electricity, LPG, and E85 have all increased substantially.

Table 11. Number and Type of AFVs by Fuel Type

\begin{tabular}{|l|l|l|l|l|l|l|l|l||l||l|}
\hline Vehicle type & E85 & HEV & BiodsI & CNG & Elec & LPG & LNG & PHEV & H2 & Total \\
\hline Car & 59,899 & 123,953 & 2,112 & 16,559 & 8,377 & 581 & 0 & 1,484 & 1 & 212,966 \\
\hline Pickup/SUV/Van & 88,755 & 4,430 & 9,133 & 13,060 & 199 & 4,877 & 0 & 16 & 23 & 120,493 \\
\hline Unknown LDV & 34,157 & 5,129 & 7,232 & 4,571 & 5,113 & 4,206 & 0 & 451 & 0 & 60,859 \\
\hline Unknown HDV & 2,548 & 533 & 42,677 & 5,206 & 38 & 1,657 & 748 & 73 & 1 & 53,481 \\
\hline Delivery Truck & 1,261 & 639 & 27,826 & 3,934 & 170 & 1,461 & 33 & 10 & 0 & 35,334 \\
\hline Transit Bus & 0 & 4,583 & 2,293 & 9,436 & 629 & 254 & 642 & 0 & 20 & 17,857 \\
\hline Patrol Car & 10,567 & 1,338 & 3 & 186 & 95 & 948 & 0 & 24 & 4 & 13,165 \\
\hline School Bus & 0 & 220 & 6,395 & 1,372 & 2 & 2,089 & 26 & 7 & 0 & 10,111 \\
\hline Refuse Truck & 0 & 15 & 2,929 & 3,619 & 8 & 6 & 991 & 6 & 0 & 7,574 \\
\hline Low- & & & & & & & & & & \\
Speed/Neighbor & & & & & & & & & & \\
hood & 0 & 96 & 105 & 0 & 3,330 & 3 & 0 & 331 & 0 & 3,865 \\
\hline Semi-Truck & 0 & 210 & 1,969 & 402 & 2 & 121 & 971 & 45 & 0 & 3,720 \\
\hline
\end{tabular}




\begin{tabular}{|l|l|l|l|l|l|l|l|l||l|l|} 
Shuttle Bus & 0 & 17 & 432 & 1,176 & 3 & 288 & 0 & 0 & 1 & 1,917 \\
\hline Motorcycle & 0 & 42 & 0 & 0 & 30 & 10 & 0 & 0 & 0 & 82 \\
\hline \hline TOTAL & 197,187 & 141,205 & 103,106 & 59,521 & 17,996 & 16,501 & 3,411 & 2,447 & 50 & 541,424 \\
\hline
\end{tabular}

In addition to asking coordinators to report vehicle types, we also asked them to provide information about vehicle ownership and the markets served by reported vehicles. As shown in Figure 8, half of the reported vehicles were owned by the general public or an unknown entity. Many of these vehicles were reported through fuel retailers. The next two largest ownership groups of AFVs are local governments and state governments, at $19 \%$ and $17 \%$, respectively. Vehicles in taxi and USPS fleets more than doubled in size in 2012, while corporate fleets increased by $2 / 3$. Government fleets (including National Park) and utilities all grew between $25 \%$ and $39 \%$. AFVs owned by unknown drivers and airports decreased approximately $40 \%$.

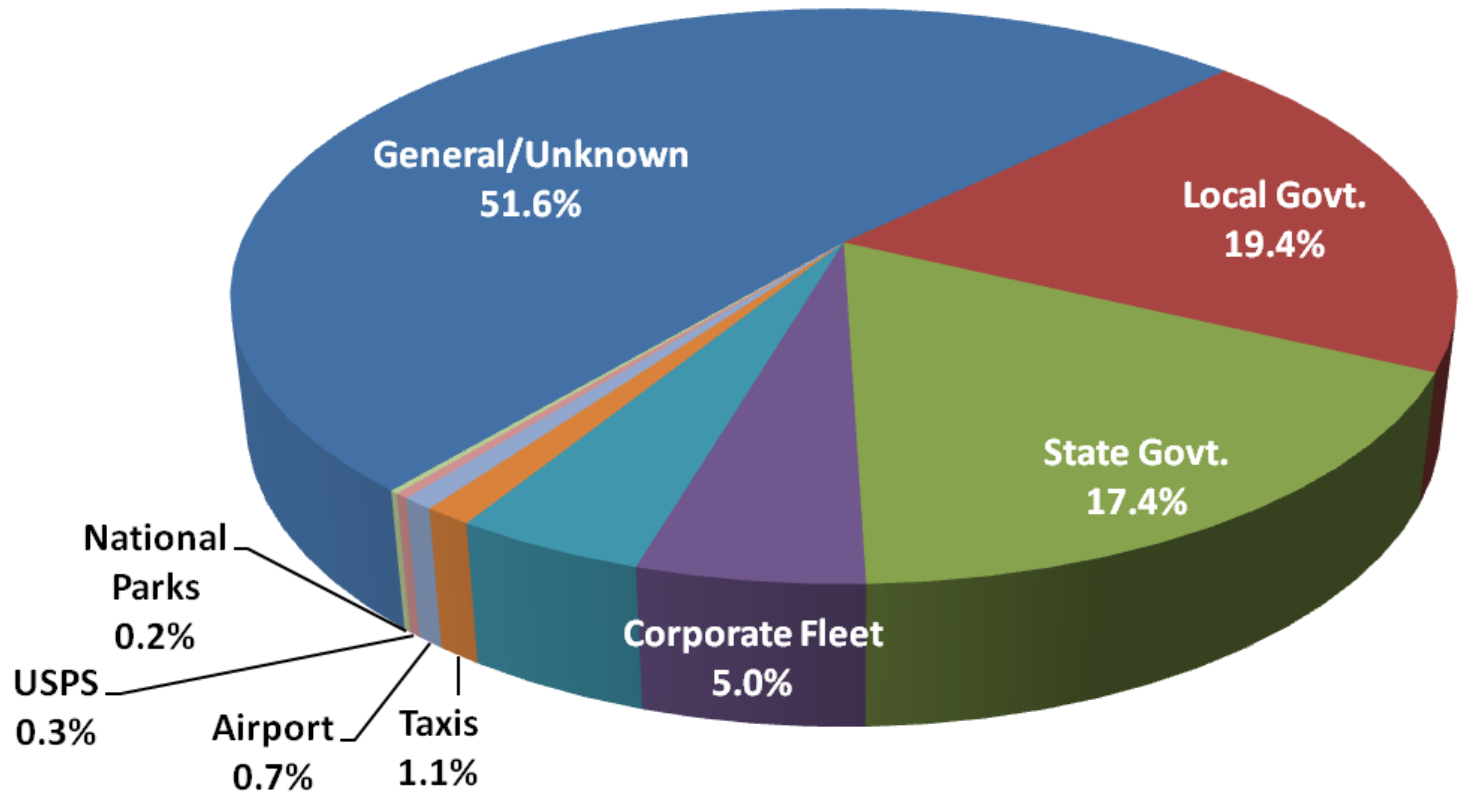

Figure 8. Percentage of total AFVs by market/owner

\section{Coordinators and Coalition Types}

Collectively, coordinators reported spending a total of 2,677 hours per week on Clean Cities tasks, or more than 130,000 total hours over the course of the year. This translates to 67 fulltime, experienced technical professionals working to reduce U.S. dependence on petroleum. For an individual coalition, the average amount of time spent coordinating Clean Cities business per week was 31 hours, and the median was 30. Both values stayed consistent from 2011 to 2012. The reporting website also gathered information on coordinator experience. The average coordinator has been on the job for six years. Half the coordinators have had more than five years of experience as of 2012, and half have had five or fewer years of experience. Twenty coordinators have been with Clean Cities for at least 10 years. 
Coalition types were tracked for the first time this year, and the relationships between coalition type and some general indicators of success were analyzed. The coalition types correspond to their host organization (generally who pays the coordinator's salary) and are listed in the first column in Table 12 below. Standalone nonprofits and independent businesses are coalition types that are self-sustaining and have no host organization.

The number of coalitions in each grouping is listed in the second column of Table 12 followed by indicators of success - such as the average number of stakeholders, average funds (including grants and dues) received in 2012, the average GGEs of petroleum reduced, and the average number of persons reached through outreach events. The highest value for each indicator is highlighted in yellow, and the lowest value is highlighted in green. It should be noted that the range of all indicators overlaps heavily between groups and the low sample size precludes statistical significance. Coalitions that are standalone nonprofits tended to have the highest number of stakeholders, while those hosted by city or county governments had the fewest. However, coalitions held by city and county governments were the most successful at bringing funds in and at reducing petroleum, while independent businesses were the least successful at those goals. Coalitions hosted in nonprofits reached the largest number of people through outreach events, while those hosted in universities reached the fewest.

Table 12. Indicators of Coalition Success by Coalition Type

\begin{tabular}{|l|l|l|l|l|l|}
\hline \multicolumn{1}{|c|}{ Coalition Type } & \multicolumn{1}{|c|}{$\begin{array}{c}\text { \# of } \\
\text { Coalitions }\end{array}$} & $\begin{array}{c}\text { Avg. \# } \\
\text { Stakeholders }\end{array}$ & Avg. Funds in & $\begin{array}{c}\text { Avg. GGE } \\
\text { Reduced }\end{array}$ & $\begin{array}{c}\text { Avg. Persons } \\
\text { Reached }\end{array}$ \\
\hline $\begin{array}{l}\text { Government - City or } \\
\text { County }\end{array}$ & 8 & 55 & $\$ 28,664,594$ & $9,752,085$ & 151,475 \\
\hline Government - State & 9 & 183 & $\$ 1,679,951$ & $3,891,821$ & 33,093 \\
\hline Independent Business & 4 & 284 & $\$ 1,365,369$ & $1,376,848$ & $1,536,349$ \\
\hline Nonprofit - Hosted & 16 & 192 & $\$ 15,365,786$ & $5,477,072$ & $5,205,128$ \\
\hline Nonprofit - Standalone & 24 & 367 & $\$ 8,736,875$ & $6,891,527$ & 140,302 \\
\hline $\begin{array}{l}\text { Regional Governing } \\
\text { Coalition }\end{array}$ & 16 & 143 & $\$ 7,983,297$ & $6,124,760$ & 877,841 \\
\hline University & 4 & 97 & $\$ 5,464,206$ & $2,803,805$ & 5,756 \\
\hline $\begin{array}{l}\text { Total/Overall Weighted } \\
\text { Average }\end{array}$ & 81 & 217 & $\$ 10,555,863$ & $5,935,699$ & $1,337,936$ \\
\hline
\end{tabular}

$1{ }^{*}$ Yellow highlights the largest (most successful) number in a column and green highlights the lowest.

\section{Project Funding}

In 2012, 57 coalitions reported receiving 187 new project awards (project-specific grants) worth a total of $\$ 122$ million. These coalitions also reported garnering $\$ 89$ million in leveraged, or matching, funds, for a combined total of $\$ 211$ million. This funding represents an 8:1 leveraging of the \$28 million program budget in FY 2012. The value of 16 of the 187 awards exceeded $\$ 1$ million each. Table 13 presents a breakdown of the number and value of awards reported by the coalitions. 
Table 13. Breakdown of 2012 Project Awards by Number and Value

\begin{tabular}{|l|l|l|l|l|}
\hline Size Category & Number & $\begin{array}{l}\text { Share of } \\
\text { Total } \\
\text { Number }\end{array}$ & Total Value & $\begin{array}{l}\text { Share of Grand } \\
\text { Total Value }\end{array}$ \\
\hline$<\$ 50,000$ & 89 & $48 \%$ & $\$ 1,323,407$ & $1 \%$ \\
\hline$\$ 50,000-\$ 99,999$ & 22 & $12 \%$ & $\$ 1,442,121$ & $1 \%$ \\
\hline$\$ 100,000-\$ 499,999$ & 47 & $25 \%$ & $\$ 10,473,145$ & $9 \%$ \\
\hline$\$ 500,000-\$ 999,999$ & 13 & $7 \%$ & $\$ 9,257,625$ & $8 \%$ \\
\hline$\$ 1 \mathrm{M}-\$ 37 \mathrm{M}$ & 16 & $9 \%$ & $\$ 99,906,017$ & $82 \%$ \\
\hline Grand Total & 173 & $100 \%$ & $\$ 122,402,314$ & $100 \%$ \\
\hline
\end{tabular}

In addition to new 2012 awards, coordinators reported the portions of previous multi-year awards spent during the calendar year. If a coordinator failed to report the amount spent during 2012, we assumed it to be the total amount of the award divided by the number of years of award duration. Coalitions reported already spending $57 \%$ of the multi-year funds they were awarded in 2012 , suggesting that projects started quickly. In 2012, coalitions helped utilize a total of $\$ 371$ million in project funds that were awarded and matched from 2006 to 2012.

The American Recovery and Reinvestment Act (ARRA) was signed into law on Feb. 17, 2009 to create jobs in all areas of the country and spur future economic development in key areas such as clean energy. Clean Cities proved to be a highly effective avenue for identifying effective, shovel ready projects across the nation and quickly funding them. In 2009, more than \$190 million of the award funding reported by Clean Cities coalitions came from ARRA, and that money attracted \$176 million in leveraged funds. In 2010, 48 more ARRA awards were distributed through 33 coalitions. In 2011, nine awards came in with $\$ 4.3$ million and leveraging an additional \$2 million in matching funds. In 2012, the final 22 awards came in with matching funds to total $\$ 70$ million. ARRA funds distributed during all four years are still being utilized, accounting for $\$ 82$ million in Clean Cities project funding in 2012.

Of the \$211 million in project awards and leveraged funds issued in 2012, \$20.9 million (10\%) was listed as coming from DOE independent of ARRA. DOE funds distributed in 2012 and previous years totaled $\$ 39$ million of the $\$ 371$ million (11\%) utilized for projects in 2012 . Funding from Clean Cities coalition support contracts was not included among the project awards, since those funds are intended to support coalition operations rather than specific projects.

\section{About the Stakeholders}

In 2012, 83 coalitions reported a total of nearly 18,000 stakeholders for an average of 217 stakeholders per coalition. These data indicate that Clean Cities coalitions are continuing to grow: the average coalition grew 43\%, from 152 stakeholders in 2011.

Participation in Clean Cities is voluntary, and coalitions draw local stakeholders from the public and private sectors. Stakeholders include local, state, and federal government agencies, large and small businesses, auto manufacturers, car dealers, fuel suppliers, public utilities, and professional 
associations. Coalitions reported that $51 \%$ of the total stakeholders were from the private sector. This composition represents a slight shift (3\%) from public to private stakeholders in 2012 .

\section{Data Sources and Quality}

Gathering data is always challenging for the coordinators, because they rely on voluntary reporting from their stakeholders. Therefore, the annual report website contains some questions related to coordinator sources and data quality. In these questions, coordinators were asked to rate the quality of their data as excellent, good, fair, or poor. The "cumulative" bar in Figure 9 presents the response breakdown for the 85 coordinators who answered the question. Twenty-six percent of the respondents classified their data as excellent, $69 \%$ as good, $4 \%$ as fair, and $1 \%$ as poor. Relative to 2011 , the poor category increased 1 percentage point, the fair category decreased 2 percentage points, the good category increased by 2 percentage points, and the percentage of coordinators who felt their data was excellent stayed the same.

We also asked coordinators how they obtained their data. They could choose one or more of the following: online questionnaires (such as survey monkey), written (paper or electronic) questions to stakeholders, phone interviews with stakeholders, coalition records, or coalition estimates. Written questions were the most used method of data gathering, accounting for $27 \%$. The next most used method was phone interviews $(26 \%)$, then coalition records $(19 \%)$, estimates $(16 \%)$, and finally online questionnaires (11\%). When compared to 2011, this breakdown represents a shift from coalition records and phone interviews toward online questionnaires and written questions. Figure 9 shows that estimates resulted in slightly lower levels of reliability than the other three collection methods. This is likely due to coordinators' confidence in the numbers that come from stakeholder fleets as opposed to the numbers they track or estimate themselves. The quality of the data collected via the other three methods was rated very similarly, from one method to the next. 


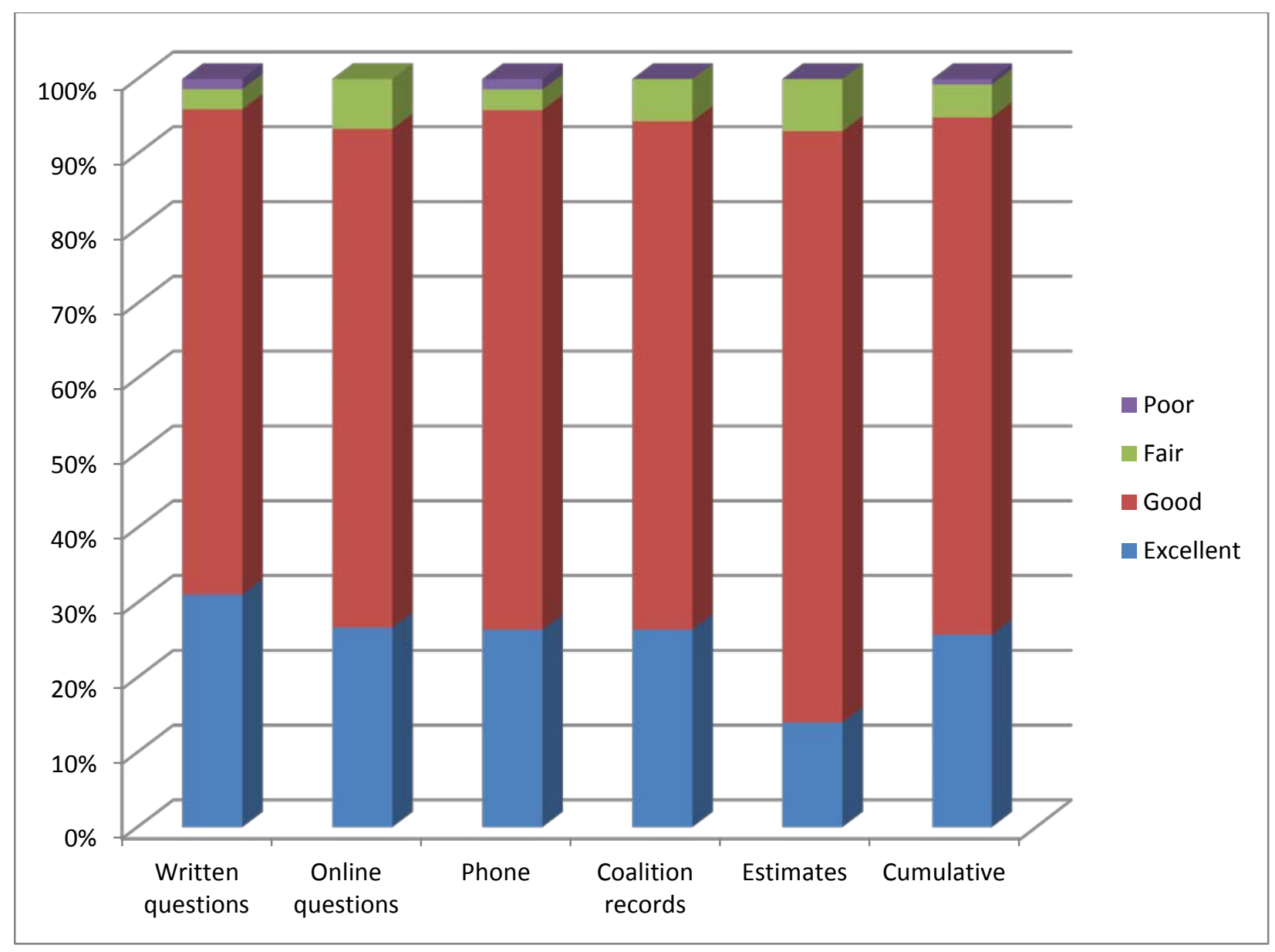

Figure 9. Data quality responses by data source

\section{Conclusion}

The Clean Cities 2012 Annual Metrics Report helps quantify the impact of the program as a whole and of the activities of individual coalitions. It shows that the Clean Cities program had a very successful year on all accounts. It outpaced its petroleum-saving goal by improving that metric $13 \%$ this year. It increased the number and diversity of AFVs and advanced vehicles on U.S. roads. The program also substantially increased its greenhouse gas savings, people reached through outreach events, stakeholder involvement, and reported data quality. The combined efforts of DOE, its national laboratories, and local Clean Cities coalitions bring together otherwise disparate groups and funding sources to accelerate the nation's progress toward petroleum savings, and thereby, toward improved energy independence, economic security, and environmental protection. 


\section{Appendix A: Clean Cities Coalitions that Completed 2012 Annual Reports}

\begin{tabular}{|l|l|}
\hline State & Coalition \\
\hline AL & Alabama Clean Fuels Coalition \\
\hline AR & Arkansas Clean Cities \\
\hline AZ & Tucson Clean Cities \\
\hline AZ & Valley of the Sun Clean Cities (Phoenix) \\
\hline CA & Antelope Valley Clean Cities \\
\hline CA & Central Coast Clean Cities \\
\hline CA & Coachella Valley Region Clean Cities \\
\hline CA & East Bay Clean Cities (Oakland) \\
\hline CA & Long Beach Clean Cities \\
\hline CA & Los Angeles Clean Cities \\
\hline CA & Sacramento Clean Cities \\
\hline CA & San Diego Regional Clean Cities Coalition \\
\hline CA & San Francisco Clean Cities \\
\hline CA & San Joaquin Valley Clean Cities \\
\hline CA & Silicon Valley Clean Cities (San Jose) \\
\hline CA & Southern California Clean Cities \\
\hline CA & Western Riverside County Clean Cities \\
\hline CO & Denver Clean Cities \\
\hline CO & Northern Colorado Clean Cities \\
\hline CO & Southern Colorado Clean Cities \\
\hline CT & Capitol Clean Cities of Connecticut \\
\hline CT & Connecticut Southwestern Area Clean Cities \\
\hline CT & New Haven Clean Cities \\
\hline CT & Norwich Clean Cities \\
\hline DC & Greater Washington Region Clean Cities \\
\hline DE & State of Delaware Clean Cities \\
\hline FL & Central Florida Clean Cities Coalition \\
\hline FL & Southeast Florida (Miami-Dade/Broward/Palm Beach/Monroe) \\
\hline GA & Clean Cities-Atlanta \\
\hline HI & Honolulu Clean Cities \\
\hline A & lowa Clean Cities Coalition \\
\hline ID & Treasure Valley Clean Cities \\
\hline IL & Chicago Area Clean Cities Coalition \\
\hline IN & Greater Indiana Clean Cities \\
\hline IN & South Shore Clean Cities \\
\hline KS & Kansas City Regional Clean Cities \\
\hline KY & Kentucky Clean Cities Partnership \\
\hline & \\
\hline
\end{tabular}




\begin{tabular}{|l|l|}
\hline State & Coalition \\
\hline LA & Louisiana Clean Fuels \\
\hline LA & Southeast Louisiana Clean Fuels Partnership \\
\hline MA & Massachusetts Clean Cities \\
\hline MD & State of Maryland Clean Cities \\
\hline ME & Maine Clean Communities \\
\hline MI & Ann Arbor Clean Cities \\
\hline MI & Detroit Clean Cities \\
\hline MI & Greater Lansing Clean Cities \\
\hline MN & Twin Cities Clean Cities \\
\hline MO & St. Louis Clean Cities \\
\hline NC & Centralina Clean Fuels Coalition \\
\hline NC & Land of Sky Clean Vehicles Coalition \\
\hline NC & Triangle Clean Cities (Raleigh, Durham, Chapel Hill) \\
\hline ND & North Dakota Clean Cities \\
\hline NH & Granite State Clean Cities \\
\hline NJ & New Jersey Clean Cities \\
\hline NM & Land of Enchantment Clean Cities (New Mexico) \\
\hline NY & Capital District Clean Communities (Albany) \\
\hline NY & Central New York Clean Cities (Syracuse) \\
\hline NY & Clean Communities of Western New York (Buffalo) \\
\hline NY & Empire Clean Cities (New York City) \\
\hline NY & Genesee Region Clean Communities (Rochester) \\
\hline NY & Greater Long Island Clean Cities \\
\hline OH & Clean Fuels Ohio \\
\hline OH & Northeast Ohio Clean Transportation (Cleveland) \\
\hline OK & Central Oklahoma Clean Cities (Oklahoma City) \\
\hline OK & Tulsa Clean Cities \\
\hline OR & Columbia-Willamette Clean Cities \\
\hline OR & Rogue Valley Clean Cities \\
\hline PA & Philadelphia Clean Cities \\
\hline PA & Pittsburgh Clean Cities \\
\hline RI & Ocean State Clean Cities \\
\hline SC & Palmetto State Clean Cities \\
\hline TN & East Tennessee Clean Fuels Coalition \\
\hline TN & Middle Tennessee Clean Cities \\
\hline TX & Alamo Area Clean Cities (San Antonio) \\
\hline TX & Dallas-Fort Worth Clean Cities \\
\hline TX & \\
\hline TX & \\
\hline UT & Loun Cities \\
\hline & \\
\hline
\end{tabular}




\begin{tabular}{|l|l|}
\hline State & Coalition \\
\hline VA & Virginia Clean Cities \\
\hline VT & State of Vermont Clean Cities \\
\hline WA & Western Washington Clean Cities (Seattle) \\
\hline WI & Wisconsin Southeast Area Clean Cities \\
\hline WV & State of West Virginia Clean Cities \\
\hline WY & Yellowstone-Teton Clean Energy Coalition \\
\hline
\end{tabular}

